\title{
Geodesign Yöntemi Kullanılarak Sürdürülebilir Kentsel Büyüme Analizi: Eyyübiye İlçe Merkezinden (Şanlıurfa) Bir Örnek Çalışma
}

\author{
Planning of Eyyübiye District Center (Şanluurfa) Using the Geodesign Method
}

\author{
Abdullah İzzeddin KARABULUT ${ }^{1}$ (D), Sedat BENEK ${ }^{2}$ (i), Fred Barış ERNST ${ }^{3}$ (D) \\ 'Doktora Öğrencisi, Harran Üniversitesi, Fen Bilimleri Enstitüsü, Uzaktan Algılama ve Coğrafi Bilgi Sistemleri 100/2000 YÖK \\ Doktora Bursiyeri, Şanlıurfa, Türkiye \\ ${ }^{2}$ Prof. Dr. Harran Üniversitesi, Fen Edebiyat Fakültesi, Coğrafya Anabilim Dalı, Şanlıurfa, Türkiye \\ ${ }^{3}$ Dr. Öğretim Üyesi, Harran Üniversitesi, Harita Mühendisliği Bölümü, Şanlıurfa, Türkiye
}

ORCID: A.İ.K. 0000-0002-9784-5549; S.B. 0000-0002-5221-9683; F.B.E. 0000-0002-7568-2582

\section{ÖZ}

1960'lı yıllardan itibaren artan kırdan kente göç, diğer yandan Suriye'de 2011 yılında iç savaşın patlak vermesiyle kaçan insanların ülkelerini terk edip Türkiye'ye sığınmalarıyla, mevcut yerleşim yerleri kaldırabileceğinden çok daha fazla insana ev sahipliği yapmaya başlamıştır. Bu durum, Eyyübiye ilçe merkezinin mevcut nüfusuna yakın bir nüfusu barındırmak zorunda kalmasına neden olmuştur. Bu hızlı nüfus artışı beraberinde insanları, sosyoekonomik faaliyetleri sürdürmek için yeni mekân arayışlarına ve bu mekânları şekillendirerek yeni yapılar inşa etmeye yöneltmiştir. Bu yerleşim birimleri, özellikle az gelirli mahallelerde yaşayanlar tarafından gecekondu yapılarını meydana getirerek çarpık kentleşmeye neden olmuştur. Bu çalışma, Eyyübiye ilçe merkezi için kentsel gelişime/değişime ilişkin öneriler sunmak üzere hazırlanmıştır. CBS yazılımlarından birisi olan Arcgis'in kullanıldığı bu çalışmada, yer tasarımında kullanılan Geodesign yöntemi ile şehrin doğal ortamla ilişkisi göz önüne alınarak, şehrin gelişimi, nüfus artış oranları ile ihtiyaç duyulabilecek yeni kentsel gelişim alanları belirlemeye çalışılmıştır. Bu çalışmada, 39 şehirsel mahallenin oluşturduğu Eyyübiye merkez ilçesindeki 39,307 hanenin bulunduğu 24 mahallede kentsel gelişim/değişime ihtiyacı olduğu saptanmıştır. $\mathrm{Km}^{2}$ ye 20,038 kişinin düştüğü bu yerleşim alanı için, "öncelikli düzenlemesi gereken" 7.89 $\mathrm{km}^{2}$ yerleşim alanı ve "öncelikli yerleşime açılması gereken" $22.61 \mathrm{~km}^{2}$ alan ile birlikte $30.35 \mathrm{~km}^{2}$ ile karşılanabilir olduğu hesaplanmıştır. Bu alanların yerleşime açılması durumunda nüfus yoğunluğunun da düşeceğinin altı çizilmektedir.

Anahtar kelimeler: Geodesign, CBS, Planlama, Eyyübiye

\section{ABSTRACT}

Since the 1960s, increased rural-to-urban migration has led to overpopulated cities. Especially with the outbreak of the civil war in Syria in 2011, people were forced to seek refuge in Turkey. This situation is the factor underlying the current population in Eyyübiye district center. Moreover, the rapid population growth resulted in the search for new places in which to continue socioeconomic activities. These settlements created informal structures that caused distorted urbanization especially in low-income neighborhoods. This study provides proposals for urban development/change for Eyyübiye district center. Using ArcGIS, a GIS software, the study intends to determine new areas for urban development given the city's development, population growth rate, and relationship with the natural environment. The study employed the geodesign method for ground design. The results indicated that 24 neighborhoods with 39,307 households in Eyyübiye central district, which consists of 39 urban neighborhoods requiring urban development/change. This residential area was composed of 20,038 people per $\mathrm{km}^{2}$. The calculation suggested that the area $30.50 \mathrm{~km}^{2}$ was affordable, $7.89 \mathrm{~km}^{2}$ of the settlement marked for regulation and $22.61 \mathrm{~km}^{2}$ for priority settlement.

Keywords: Geodesign, GIS, Planning, Eyyübiye

Başvuru/Submitted: 15.03.2021 • Revizyon Talebi/Revision Requested: 11.05.2021 • Son Revizyon/Last Revision Received: 18.05 .2021 • Kabul/Accepted: 28.05 .2021 - Online Yayın/Published Online: 16.06 .2021

Sorumlu yazar/Corresponding author: Abdullah Izzeddin KARABULUT / ikarabulut@harran.edu.tr, karabulut6363@gmail.com Atıf/Citation: Karabulut, A. I., Benek, S., Ernst, F. B. (2021). Geodesign yöntemi kullanılarak Eyyübiye ilçe merkezinin (Şanlıurfa) planlanması. Cografya Dergisi, 42, 251-269. https://doi.org/10.26650/JGEOG2021-897149 


\section{EXTENDED ABSTRACT}

The Industrial Revolution increased rural-to-urban migration and led to the rapid increase of the population. However, World Wars I and II, the Great Depression, civil conflicts, and forced migration resulted in mass poverty, unemployment, and economic problems, which led to the emergence of new informal settlements. This study discusses whether such settlements are humanly habitable.

Since the 1960s, increased rural-to-urban migration and the outbreak of the civil war in Syria has driven people to take refuge in Turkey until its population increased to an overwhelming number. In fact, border provinces, such as Şanliurfa, were greatly affected by the civil war in Syria. This caused Şanliurfa to accommodate a population close to its current population. The Syrian migration worsened the urban problems that emerged during rural-to-urban migration. As such, the rapid population growth forced people to seek and build new settlements to continue their socioeconomic activities. This situation resulted in the creation of informal settlements that caused distorted urbanization, especially in low-income areas.

This study features a similar urbanization in Şanlıurfa City, with a population of 276,352, area of $15.85 \mathrm{~km}^{2}$, and population density of 17.45 persons $/ \mathrm{km}^{2}$, and the Ayyubids considered the natural environment to be developed for the urban transformation projects of the district according to the socioeconomic condition of the people before accepting recommendations for building a livable city. This study used the ArcGIS software to determine new areas for urban development, which may be needed for the development of the city and the increasing population growth rate, considering the relationship of the city with the natural environment and using the geodesign method to design such an area.

In the first stage, we evaluated data regarding geodesign using various sources for this purpose. Especially in the literature review, the geodesign method was considered as the precursor of this field, and many have benefited from the work of experts, such as Hrishikesh Ballal, Carl Steinitz and Brian A Orland, Jack Dangermond, and Ming-Chun Lee. In addition, documents shared on the cloud-based Geodesignhub were used. Several studies, including theoretical, conceptual, and infrastructural planning, have been established in relation to the subject.

In the second stage, we conducted fieldwork in the Eyyübiye district center, collecting information about the study area using standard methods in geographical research, such as observation and examination.

Geodesignhub is an internet-based software built for geodesigning, which was used to create 10 different eligibility maps, namely, housing compliance, green space (bio-conservation) compliance, water infrastructure and drainage compliance, transportation compliance, energy electricity compliance, agriculture compliance, industry compliance, central business compliance, public space compliance, and archaeological tourism compliance. In general, these eligibility maps are used to determine the plots that may be suitable for the projects to be created.

In this study, two scenarios were applied, namely, the study of settlement areas as a result of normal development and the study of regular settlement areas.

A cross-impact analysis map for a housing system under normal development scenario was examined using Geodesignhub, which showed that residential areas to be made on agricultural areas had the most negative impact. The most positive impact was observed only in areas connected with the southern part of the planned areas. During this review, we found that these areas had a bad impact on the housing system, and the cross-impact analysis map for the housing system revealed that these areas should be used for agriculture. Moreover, these residential areas have a positive effect when analyzing the impact of both the housing system and other systems. Based on the cross-impact analysis of these identified residential areas, the residential impact analysis was positive, whereas the agricultural impact analysis was positive for existing residential areas and neutral for other areas.

The results of this study indicated that the total surface measurement in the Eyyübiye district center is $12.21 \mathrm{~km}^{2}$, which is formed by 39 urban neighborhoods. The total population is 244,683; moreover, 39,307 households in 24 neighborhoods need urban development. 
The average household size is 6.22 people, and the population density is 20,038.34 people per $\mathrm{km}^{2}$ for these settlements. Furthermore, a $7.89 \mathrm{~km}^{2}$ settlement area classified under the category "priority should be arranged" and a $22.61 \mathrm{~km}^{2}$ area under "priority should be opened to settlement" could be covered, for a total of $30.50 \mathrm{~km}^{2}$. 


\section{GÍRIŞ}

Günümüzün temel problemlerinden biri çevre sorunları ve dolayısıyla yaşanılabilir bir ortam konusudur. $\mathrm{Bu}$ sorun, politikacılar, kent planlamacıları, akademisyenler ve çevreci hareketler başta olmak üzere pek çok disiplin, politik yapı, sivil toplum kuruluşu ve hareketi nezdinde sıcaklığını koruyan bir konu olmaya devam etmektedir. Bir taraftan Sanayi Devrimi sonrası artan kırdan kente göç ve nüfusun hızlı artışı, diğer taraftan da günümüz dünyasındaki savaşların, buhranların ve iç çatışmaların bir sonucu olarak zorunlu kitlesel göçlerin artışının yoksulluk, işsizlik gibi ekonomik sorunlar, çarpık kentleşme gibi olguların harmanlanmasıyla gecekondu gibi yeni yerleşim yerleri ortaya çıkmaktadır.

İnsan, ilk ortaya çıktığı andan itibaren barınma, beslenme amaçlı ihtiyaçlarını karşılamak için doğal ortam üzerinde değişim ve dönüşümler yapmaktadır. Nüfusun giderek artması ve insanların kültür seviyesinin yükselmesi hem insanın doğal ortamla olan etkileşimi hem de insanın doğal ortam üzerindeki tahakkümünü arttırmıştır. Özellikle Sanayi Devrimi ile birlikte gelişen hızlı şehirleşme olgusu bu etkiyi daha da hızlandırmıştır. Gerek hammadde kullanımı gerek inşa edilen sosyokültürel yapılar, doğal ortam üzerinde insan kaynaklı olguların etki alanını genişletmiştir. İnsanoğlunun kültür seviyesi ve bilgi birikiminin süreç içinde artması, onu doğal ortamdan faydalanmayı sömürü düzeyine getirme noktasına taşımıştır. Bununla birlikte, büyük çaplı kitlesel göçler de insan ile mekân arasındaki ilişkinin kimyasını bozmakta, bu ilişkinin değişimine ve dönüşümüne, hızlandırıcı ve derinleștirici bir etki yapmaktadır (Ekici ve Tuncel, 2015, s. 12'den aktaran Baydemir, 2018, s. 35). $\mathrm{Bu}$ etkilerden biri de şüphesiz ki, göç hareketine bağlı, hızlı kentleşme ve dolayısıyla gecekondu semtlerin, getto alanlarının, çarpık kentleşmelerin ortaya çıkmasıdır.

Kentsel dönüşüm, doğal ve tarımsal alanların şehir ve banliyölere dönüştürülmesinden veya yerleşimlerin yeniden yapılandırılmasından dolayı hızlı arazi kullanımı değişikliği olarak tanımlanmaktadır (Pickett vd., 2013, Aktaran; Hayeka U.Wissen, 2016). Dünya nüfusunun yarısından fazlası hâlihazırda kentsel alanlarda yaşıyor olduğundan, daha sürdürülebilir bir kentsel dönüşümün yollarını bulmaya acil ihtiyaç vardır (BM Habitatı, 2012; Childers, Pickett, Grove, Odgen ve Whitmer, 2014).

Bu bağlamda, bir taraftan 1960'lı y1llardan itibaren artan kırdan kente göç, diğer yandan da Suriye'de 2011 yılında iç savaşın patlak vermesiyle beraber iç savaştan kaçan insanların ülkelerini terk edip Türkiye'ye sığınmalarıyla mevcut yerleşim yerleri kaldırabileceğinden çok daha fazla insana ev sahipliği yapmaya başlamıştır. Nitekim, Suriye'deki bu iç savaştan, Şanlıurfa gibi sınır illeri fazlasıyla etkilenmiştir. Daha önce kırdan kente göç ile yaşanan kentsel sorunların üzerine Suriyeli göçünün de eklemlenmesiyle bu sorunlar daha da derinleşmeye başlamıştır. $\mathrm{Bu}$ hızlı nüfus artışı beraberinde insanları, sosyoekonomik faaliyetleri sürdürmek için yeni mekân arayışlarına ve bu mekânları şekillendirerek yeni yapılar inşa etmeye yöneltmiş̧tir.

Dolayısıyla bu çalışma, Şanlıurfa şehrinde benzer özellikte bir şehirleşmeye sahip olan Eyyübiye ilçe merkezinin kentsel dönüşüm projeleri için doğal ortam özellikleri ile insanların sosyoekonomik durumlarına uygun yaşanılabilir bir kent inşa etmek için kentsel gelişime/değişime ilişkin öneriler sunmak üzere hazırlanmıştır. CBS yazılımlarından biri olan Arcgis'in aktif biçimde kullanıldığı bu çalışmada, yer tasarımında kullanılan Geodesign yöntemi ile șehrin doğal ortam ile ilişkisini göz önüne alarak, şehrin gelişimi, nüfus artış oranları ile ihtiyaç duyulabilecek yeni kentsel gelişim alanları belirlenmeye çalışılmaktadır. Ayrıca Geodesign yeni bir metodoloji ve Türkiye'de bu konuda çok az çalışma yapılmıştır. Bu çalışma ülkemizde Geodesign yönteminin kullanımı açısından öncü olma niteliğindedir.

\section{METERYAL VE YÖNTEM}

\subsection{Veri}

İlk aşamada çalışma konusu ile ilgili olarak literatür taraması yapılmıştır. Geodesign ile ilgili olarak kavram ve kuramlar incelenmiș ve bu amaçla çeșitli kaynaklardan faydalanılmıștır. Özellikle yapılan literatür taramasında Geodesign yöntemi hakkında bu alanın öncülleri olarak kabul edilen; Hrishikesh Ballal, Carl Steinitz ve Brian A Orland, Jack Dangermond, Ming-Chun Lee gibi uzmanların çalışmalarından istifade edilmiştir. Ayrıca bulut sistemi tabanlı yürütülen Geodesign Hub sitesinde paylaşılan dokümanlardan da yararlanılmıştır. Yapılan bu araştırmalar, konu ile ilgili olarak kavramsal, kuramsal ve planlama noktasında altyapı oluşturulmuştur.

İkinci aşamada, Eyyübiye ilçe merkezinde saha çalışması yapılarak coğrafya araştırma yöntemlerinden gezi, gözlem ve inceleme yöntemleri kullanılarak çalışma alanı hakkında bilgiler toplanmıştır.

Bu çalışmada kullanılan veriler;

* MTA'dan temin edilen ve çalışma alanını içeren 1/100.000 ölçekli jeoloji paftası, 
* Harita Genel Müdürlüğü’nden elde edilen 1/25.000 ve 1/5.000 ölçekli topografya haritaları,

* Haritalara altlık oluşturmak ve çeşitli analizler yapmak için Landsat 5 ve Landsat 8 MSS, TM, ETM uydu görüntüleri,

* Eyyübiye ilçe merkezine ait farklı zamanlarda çekilmiş fotoğraflar,

* TÜİK'ten alınmış nüfus verileri,

* Eyyübiye ilçesine ait Kültür Varlıklarını Koruma Bölge Kurulu Müdürlüğü'nden alınmış arkeolojik koruma alanı verileri,

* Çevre ve Şehircilik Bakanlığı Mekânsal Planlama Genel Müdürlüğü tarafından hazırlanmış Şanlıurfa iline ait n41 (1/100.000 ölçekli) çevre düzen planı.

Çalışmada gerek birincil veri kaynaklarından gerekse nitel olan ikincil veri kaynaklarından elde edilen veriler, CBS yazılımlarından biri olan Arcgis 10,5 kullanılarak tematik tabakalar oluşturulmuştur. Ardında yer tasarım süreci, yani Geodesign yöntemi uygulanmıştır.

Geodesign yönteminin avantajı, yapılması istenilen projeler için sistem alt yapısı oluşturulduktan sonra CBS bilgisi olmadan bile kolayca sistem üzerinde proje üretip bu üretilen projelerin doğal ortama etkisi belirlenebilir ve senaryolar oluşturulabilir. Bundan dolayı bu yöntem tercih edilerek https:/www. geodesignhub.com internet adresinde bulut tabanlı yazılım olan Geodesign yazılımı kullanılmıştır. Geodesign yönteminin uygulanabilmesi için 10 adet uygunluk haritası belirlenmiştir. Bu uygunluk haritaları Arcgis 10.5 yazılımı ile oluşturulmuştur. Bu çalışmada iki senaryo önerilerek yürütülmüştür. Çalışmanın ilk senaryosu şehrin normal gelişim durumu devam etmesi, ikinci senaryo ise düzenli şehirleşme önerisi verilerek 2035 yılı durumları karşılaştırılarak değerlendirilecektir.

Geodesign yönteminin internet tabanlı yazılımı olan Geodesign Hub'a (https://www.geodesignhub.com) uygun olarak belirlenen 10 farklı uygunluk haritası oluşturulmuştur. $\mathrm{Bu}$ haritalar konut uygunluğu, yeşil alan (biyokoruma) uygunluğu, su altyapısı ve drenaj uygunluğu, ulaşım uygunluğu, enerji elektrik uygunluğu, tarım uygunluğu, endüstri uygunluğu, merkezi iş alanı uygunluğu, kamusal alan uygunluğu ve arkeolojik turizm uygunluğudur. Oluşturulması istenen projelere uygun olabilecek arazileri belirlemek için genel olarak bu uygunluk haritaları belirlenmiştir.
Her bir uygunluk haritası için ayrı ayrı kriterler belirlenmiş ve bu kriterlere uygun veriler CBS yazılımlarından biri olan Arcgis ortamında sayısallaştırılmıştır. Belirlenen bu kriterler daha sonra bu sayısal veriler ile çakıştırma analizi uygulanıp alt sınıflar belirlenmiştir. Her bir uygunluk haritası kendi içinde 5 sınıftan oluşmakta ve her bir sınıf bir renk ile ifade edilmektedir.

Sonraki süreçte bu sistemler Geodesign Hub sayfasına yüklenerek planlama aşamasında optimum karar almak için bilgisayar ortamında iki senaryo ile haritalar meydana getirilmiştir. İlk senaryoda yerleşme alanlarının geçmişteki büyümesi göz önüne alınarak, doğal ortama dikkat edilmeden ve nüfus artış hızına bağlı olarak olası yerleşmeye açılabilecek alanlar tespit edilmiştir. Ayrıca, bu yeni yerleşmeye açılmış olan alanların doğal ortama etkisi tespit edilmiştir. İkinci senaryoda ise yerleşme alanlarının geçmişteki büyümesi göz önüne alınarak, doğal ortam özellikleriyle tarım alanlarına dikkat edilerek nüfus artış hızına bağlı olarak olası yerleşmeye açılabilecek ve açılması gereken alanlar tespit edilmiştir. $\mathrm{Bu}$ senaryoların üretilmesinde Eyyübiye ilçe merkezinin nüfus gelişim durumu incelenmiş ve gelecekte insanların yaşamlarını sürdürebilmek için ihtiyaç duyulan alan hesaplanmıştır. $\mathrm{Bu}$ çalışmada senaryolar bir sorunun aynı anda birden çok yönünü hesaba katmayı sağladığından önem arz etmektedir.

\subsection{BİR ANALİZ YÖNTEMİ OLARAK "GEODESİGN"}

19. yüzyıldan itibaren ekoloji ve çevre bilinci geliştikçe sürdürülebilir bir çevre anlayışı da gelişmeye başlamıştır. Ekoloji, belirli bir alanda bulunan canlılar ile bunları saran cansız çevrenin karşılıklı ilişkileri ile meydana gelen, süreklilik oluşturan bir sistemdir. İlk defa bilim adamı Ernst Haeckel tarafından canlıların birbiri ve çevresi ile ilişkilerini inceleyen bilim dalı olarak kullanmıştır (Erinç, 1984, s. 7). Bu gelişme ile planlama yapılırken, doğal denge ile uyumlu sürdürülebilirlik ilkesine uygun hareket edilmeye başlanmıştır. Bu bağlamda planlama çalışmaları, geleneksel yöntemler ile yapılmaktayken (Erinç, 1959), günümüzde CBS ile gelişen Geodesign yöntemi doğal ortam özelliklerine uygun tasarım aracı olarak kullanılmaya başlanmıştır (Dangermond, 2009; Steinitz, 2012; Foster, 2016; Lee, 2017; Çullu, 2019; Ernst, 2020).

Geodesign kelimesi, ilk kez 1993 'te Alman şehir plancı Klaus R. Kunzman tarafindan "Geodesign: Chance oder Gefahr?" adlı makalede kullanılmıştır (Ernst, 2016, s. 510). Geo, yer küre yani coğrafyayı tanımlarken, design, yani tasarım ise mevcut sorunlar ve amaçlar ile hedefe uygun planlar üretmeyi belirtir. Geodesign, politikacıların, idarecilerin ve yerel yöneticilerin bilinçli kararlar 
verip uygulayabilmeleri için tasarımcılar ve planlamacılar tarafindan coğrafi mekân teknolojilerinin rolünün bir projenin analiz, tasarım ve aynı zamanda uygulama aşamaları boyunca daha doğru ve daha iyi çözümler üretip görselleştirmek için formüle edilerek genişletildiği süreçtir. Başka bir ifade ile coğrafi ortamı bilişim teknolojisini kullanarak planlama sürecidir. Yer tasarım süreci yani Geodesign yöntemi planlama aşamasında optimum karar almak için CBS ile toplanan verilerin bilgisayar ortamında farklı senaryolar ile simülasyonlar yapma işlemleridir (Lee, 2016, s. 9). Senaryolar, bir sorunun aynı anda birden çok yönünü hesaba katmayı sağlar. CBS destekli planlama araçlarının sunduğu analitik ve haritalama fonksiyonları, büyüme ve gelişme modellerinin olasi etkilerini ve potansiyel maliyetini tahmin etme imkânı sağlamaktadır. Bu tahminlerden elde edilen bilgiler, karar vericilerin senaryoları topluluğun ihtiyacını karşılamada ne kadar iyi performans gösterdiklerini ve bu planların uygulamasının muhtemel sonuçlarının değerlendirmesinde yardımcı olur. Simülasyon işleminin avantaj1, çeşitli senaryolara göre oluşabilecek farklı durumları öngörebilme imkânı vermektedir.

Geodesign kuramının temeli, coğrafi bilginin doğru şekilde yorumlanması ve analiz edilmesi düşüncesidir. Karmaşık sistemler bütünü olan doğal ortam ve insan ihtiyaçlarını daha doğru ve etkili bir şekilde tanımlanması, yorumlanması ve planlanması için bilgisayar teknolojisi sayesinde zaman ve maliyet açısında avantajları ile Geodesign fikri ön plana çıkmıştır (Dangermond, 2009). Geodesign doğal faktörlere bağlı tasarım alternatiflerini sunan, karar verme süreçlerini etkileyen ve destekleyen bir araçtır (Çömert vd., 2016, s. 20).

Geodesign'in tarihsel gelişimine bakıldığında; Geodesign'in öncüsü sayılan Ian Mcharg'ın tasarım üzerine fikirleri Geodesign temelini oluşturmaktadır. Ian Mcharg'ın 1969'da kaleme aldığı 'Doğa İle Tasarım' (Design With Nature) kitabında ekolojik temelli planlama kararlarının alınması ve doğanın tasarım üzerindeki etkisinden bahsetmiştir. Ona göre doğal sistemlerin kapsamlı ve sistematik envanteri olmaksızın planlama yapılamaz ve bunu "ekosistem envanteri" olarak belirtir (Memlük, 2009, s. 26-27). Tabakalar şeklinde oluşturmuş olduğu haritaları üst üste koyarak çakıştırma yöntemi ile planlarını oluşturmuştur (Değerliyurt ve Çabuk, 2015, s. 300). Ian Mcharg kavram olarak Geodesign kullanmasa da doğa ile tasarım ilişkisi üzerinde durmuştur. Ayrıca Mimar Lloyd Wright (1867-1959) organik mimari tanım ile yapının çevresindeki coğrafi unsurlarla kullanımı üzerinde durulmuştur (Şenöz, 2013, s. 49). Richard Neutra, 1954'te 'Tasarım ile Hayatta Kalma' (Survival Throug Desing) kitabında doğal koşullar ve çevre unsurların mimari tasarım uygulanma yaklaşımından bahsetmiştir (Dangermond, 2009).
Günümüzde ise, Carl Steinitz Geodesign öncüsü sayılmaktadır. Carl Steinitz coğrafyanın tasarım üzerindeki etkisinden bahsederek, coğrafyaya uygun yapılan tasarımlar Geodesign uygun olduğunu belirtir. Dangermond ise Geodesign hem yeni hem de eski bir düşünce olduğunu savunur. Ona göre tasarım, doğa ile tasarım demektir (Şenöz, 2013, s. 44; Çömert vd., 2016, s. 20). Steinitz'e (2012) göre planlama coğrafi bilgi, insan ihtiyaçları, profesyonel tasarım ve bilgi teknolojileri temelleri üzerinde yapılabilir (Ervin, 2015).

Steinitz'ın Geodesign çerçevesi iki temel bölüm ve 6 aşamalı bir sistemdir. Birinci bölüm (Asseessment) çalışma yürütülecek alanı değerlendirilir ve Geodesign sisteminin ilk üç aşaması yürütülür. İlk aşama çalışma yürütülecek alanın ortam özellikleri belirlenir. İkinci aşamada çalışma alanının mevcut durumunu tanımladıktan sonra üçüncü aşamada ise çalışma alanının eksiklik, ihtiyaçları ve kapasitesi değerlendirilir.

İkinci bölümde (intervention) ise müdahale, değiştirme bölümüdür. Sistemin kalan üç aşaması uygulanır. Dördüncü aşamada alternatif plan ve senaryolar belirlenir. Beşinci aşamada yapılacak olan müdahalelerin sonuçları değerlendirilir. Son aşama karar verme aşamasıdır ve çalışma alanı için en uygun senaryo tespit edilir ve sistem en iyi sonucu bulana kadar sürekli bu aşamalar baştan tekrarlanır (Lee ve Gamez, 2017, s. 344; Foster, 2016, s. 95; Şekil 1).

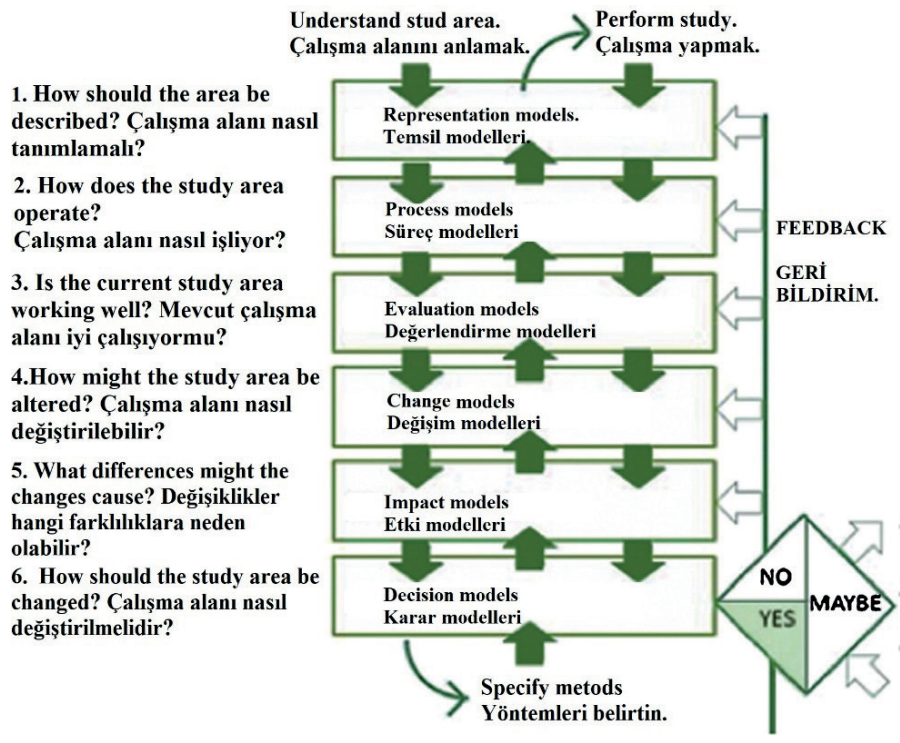

Şekil 1: Carl Steinitz Tarafından Oluşturulan Geodesign Sürecinin Altı Modeli.

Figure 1: Six Models Of The Geodesign Process Created By Carl Steinitz. 


\section{ARAŞTIRMA ALANININ GENEL DURUMU VE SINIRLARI}

\subsection{Araştırma Alanı ve Yakın Çevresi}

Her bilimin kendine özgü öne çıkan temel kavramları vardır. Kimyada element, biyolojide organizma, fizikte kütle ve enerji, ekonomide arz ve talep ne ise, coğrafya için de lokasyon, yer, mekân ve bölge bu nitelikte kavramlardır (Tümertekin, Özgüç, 2006, s.59'den aktaran Benek ve Şahap, 2016). Bu çalışmanın araştırma alanı Şanlıurfa ilinin merkez ilçelerinden Eyyübiye ilçesinin şehirsel kısmına, başka bir ifade ile Şanlıurfa şehrinin Güney kısmına tekabül eden ve idari olarak da Eyyübiye ilçesi sınırları arasında kalan şehirsel alan oluşturmaktadır.

Çalışma alanındaki yerleşimler Harran Ovası'nın kuzeykuzey batısı ile Çaykuyu Platosu'nun geçiş kuşağında, jeomorfolojik olarak bir yamaç üzerinde gelişmiştir. Yükselti basamağı ortalama olarak $400 \mathrm{~m}$ ile $600 \mathrm{~m}$ arasındadır. $\mathrm{Bu}$ yükselti değeri kuzeye çıkıldıkça artmakta iken, güneye gidildikçe ise azalmaktadır. Çaykuyu Platosu ile Harran Ovası arasındaki yamaç bölümünde, mevsimlik akarsuların platodan getirmiş olduğu kil, kum, çakıl gibi malzemeleri eğimin azaldığı yerlerde biriktirmesi ile birikinti koni şekilleri oluşmuştur (Şekil 2).
Çalışma alanı ve yakın çevresi iklim tasnifine göre subtropikal iklim kuşağının Akdeniz iklim sektöründe gösterilen Güneydoğu Anadolu Bölgesine girmektedir. Çalışma alanı, Akdeniz iklim sektöründe yer almakla beraber, hava kütleleri tasnifine göre de orta enlem iklimleri grubuna dâhil olmaktadır. Bu nedenle yaz aylarında tropikal hava kütlelerinin, kış aylarında da kısmen tropikal olmakla beraber polar hava kütlelerinin etkisi altına girmektedir. Bölgenin hâkim rüzgâr yönü Kuzey ve Kuzeybatıdır.

\subsection{Eyyübiye İlçe Merkezi Yerleşim Alanlarının Genel Durumu}

Çalışma alanına giren yerleşim alanlarını; Geleneksel Urfa Evleri'nin bulunduğu alanlar, yasal koruma altına alınan arkeolojik alanlar, turistik ve doğal koruma alanları ile kentsel değişime ihtiyaç duyulan alanlar şeklinde gruplandırmak mümkündür.

Çalışma alanı olan Eyyübiye ilçe merkezinde 276,352 kişi yaşamakta olup, alansal olarak da $15,85 \mathrm{~km}^{2}$ 'ye tekabül etmektedir. Çalışma alanında nüfus yoğunluğu 17,453 (km²/kişi)'dir.

Şanlıurfa şehrinin farklı dönemlerdeki uydu görüntülerine bakıldığında Eyyübiye ilçe merkezine tekabül eden kesiminin

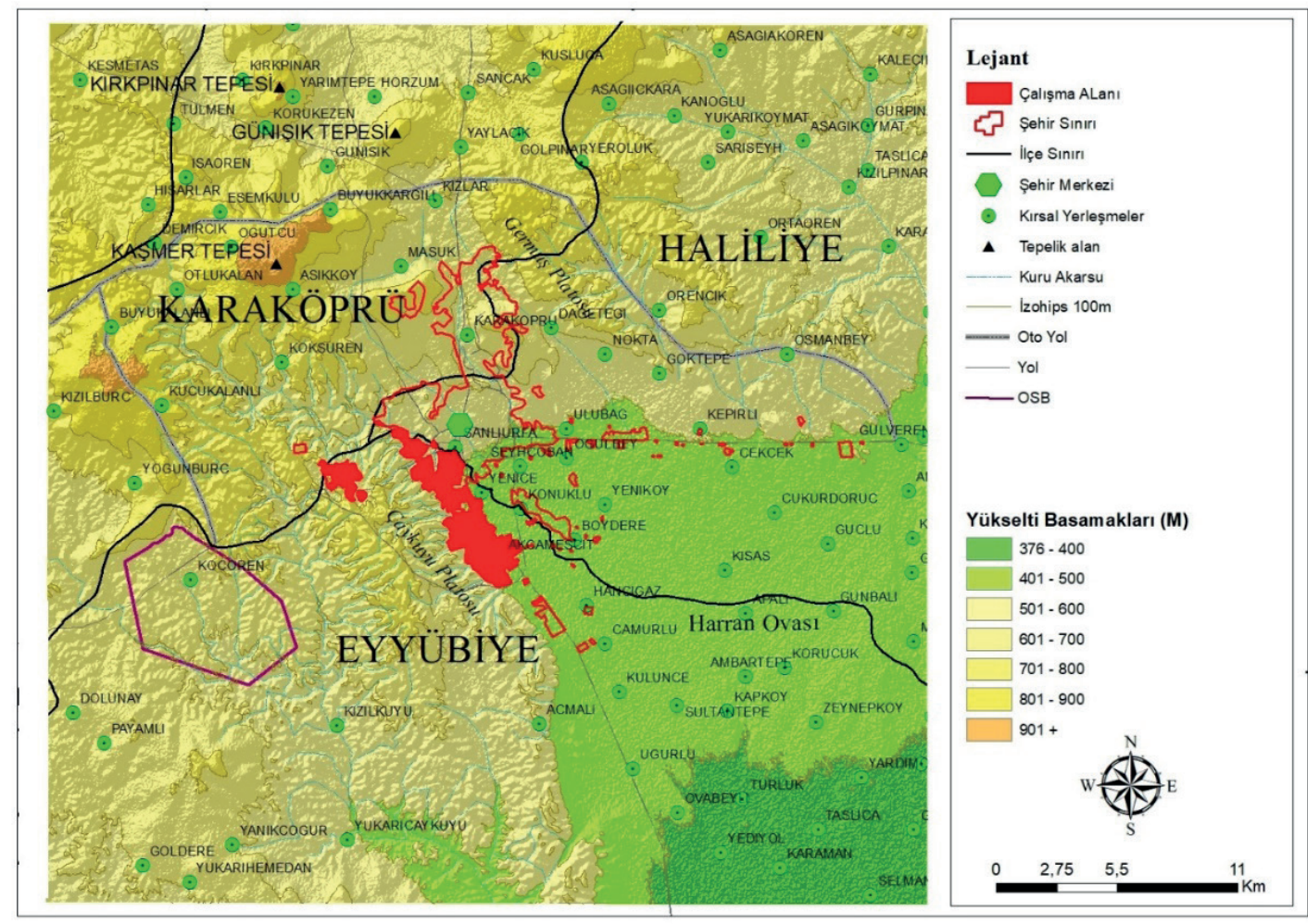

Şekil 2: Çalışma Alanı ve Yakın Çevresinin SYM Haritası.

Figure 2: DEM Map of the workspace. 
konut amaçlı arazi kullanımının yıllara göre güneye yani Harran Ovası'na doğru bir gelişim gösterdiği görülmektedir. 1985 yılında konut amaçlı 4,03 $\mathrm{Km}^{2}$ 'lik bir alan kullanılmakta iken, 1990'da 5,14 Km², 2000'de 10,38 Km² ve 2015'de 13,55 Km²'lik alan kullanılmıştır. 2018 yılında ise $15,85 \mathrm{~km}^{2}$ arazi kullanılmıştır (Şekil 3). Eyyübiye ilçesindeki şehirsel yerleşim alanları güneye doğru gelişmekte olduğu görülmektedir. İnsanlar, konut ihtiyacını karşılamak için eğimli ve engebeli arazi yüzeyleri yerine az eğimli arazi yüzeylerini tercih ettiklerinden şehir platoya doğru gelişmemiştir.

Çalı̧̧ma alanında evler çoğunlukla müstakil evler olup ortalama kat sayısı 2'dir. Eyyübiye ilçe merkezinde yer alan tarihi dokular ve yakın çevresi hariç, büyük oranda son 50 yıl içerisinde, özellikle kırsal alandan aldığ 1 göçlerle oluşmuştur. Dolayısıyla, ilçe merkezinde yaşayanların, sosyoekonomik olarak çok az bir kesimi orta gelirli iken, geri kalan büyük çoğunluğu ise alt gelirli ailelerden oluşmaktadır. 2011 Suriye İç Savaşı sonrasında Suriyelilerin yoğunluklu tercih ettiği bir alan olması münasebetiyle, ilçe merkezinde çok az mahalle/semte düzenli iken, geri kalan mahalle/semtlerde büyük oranda düzensiz bir görünüme sahiptir (Fotoğraf 1).

Eyyübiye ilçesinin toplam nüfusu 379.123 kişidir. $\mathrm{Bu}$ nüfusun 191.090'nı erkek, 188.011'i ise kadındır. Bu nüfusun \%73'ü şehirde, \%27'si kırsal alanda yaşamaktadır. Eyyübiye ilçesi şehirsel alanda kalan mahallelerde nüfusun 139.544'ü erkek, 136.810'u kadın olmak üzere toplam 276.354 kişi bulunmaktadır.

Eyyübiye ilçesi şehirsel alanda kalan mahallelerde 0-14 yaş arasında 113.771 kişi, 15-64 yaş arasında 152.834 kişi, 65 yaş üstü ise 9.749 kişi bulunmaktadır. Bu mahallelerin bağımlı nüfus oranı \%44,69' dur. Eyyübiye ilçesinde 2014 yılı doğurganlık hızı 5,26 iken 2018 yılında 4,81 ile Şanlıurfa ve Türkiye ortalamasının üzerindedir. İlçede genel olarak doğurganlık hızı giderek düştüğü anlaşılmaktadır.

\subsection{Eyyübiye İlçesinin Nüfus Artıșı Hızı}

Şanlıurfa merkez ilçelerinin doğurganlık hızı ve nüfus artış hızları karşılaştırıldığında aralarında ters bir orantı olduğu görülmektedir. 4,84 olan Eyyübiye ilçesinin doğurganlık hızı 4,13 olan Şanlıurfa ilinin doğurganlık hızının üzerinde iken, Haliliye ve Karaköprü ilçeleri il doğurganlık hızının altında doğurganlık hızına sahiptir. Ancak nüfus artış hızı Şanlıurfa ilinde binde 24,9 iken, Eyyübiye ilçesinde nüfus artış hızı binde 8,4' tür. Ayrıca Haliliye ilçesinde nüfus artış hızı 3,0 iken, Karaköprü ilçesi 115,4' tür. Bu durum diğer merkez ilçelerden Karaköprü ilçesine nüfusun göç ettiğini göstermektedir (Şekil 4).

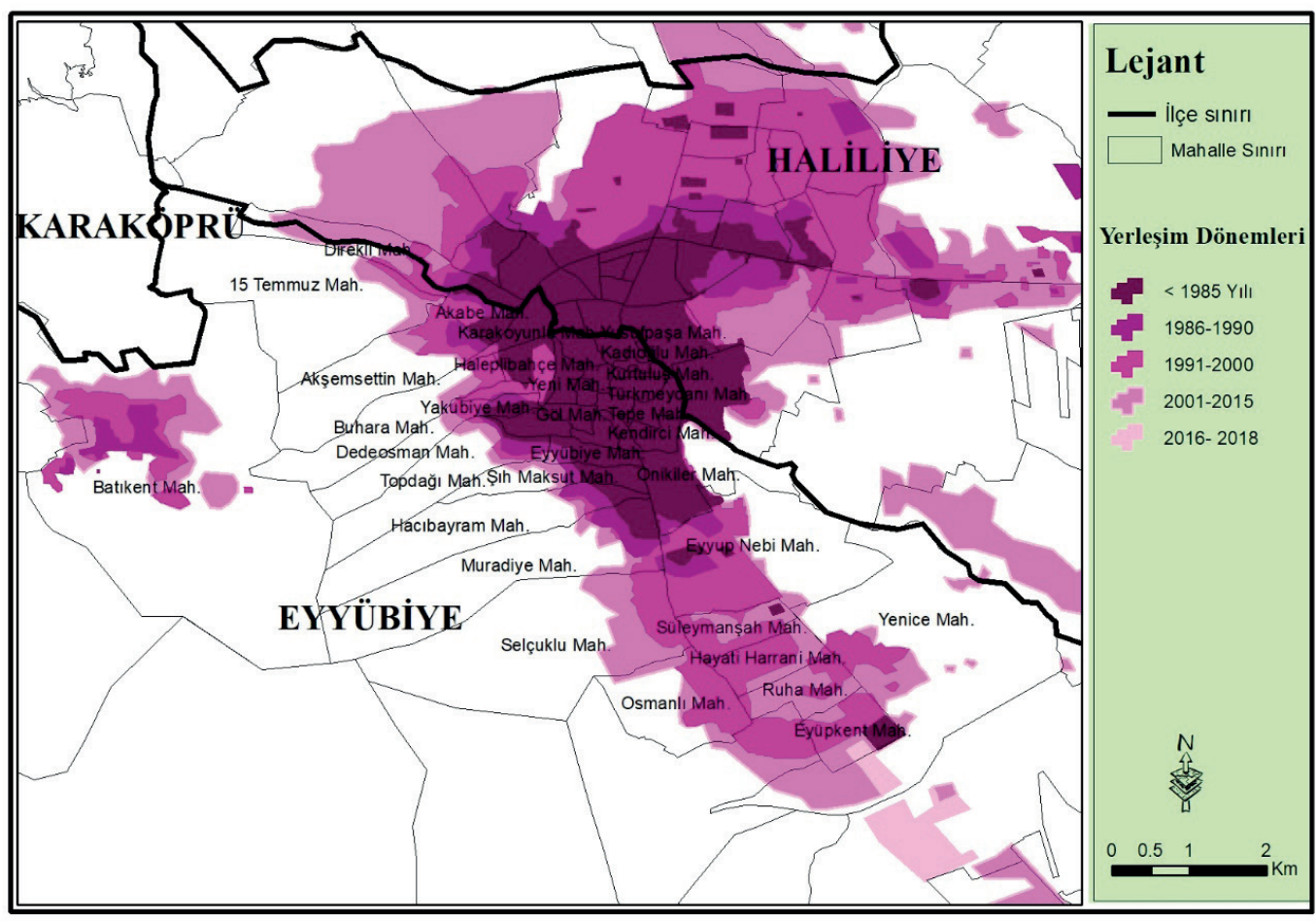

Şekil 3: Çalışma Alanı ve Yakın Çevresinin Yerleşme Amaçlı Dönemsel Gelişimi.

Figure 3: Periodic development of the work area and its immediate environment for settlement purposes. 


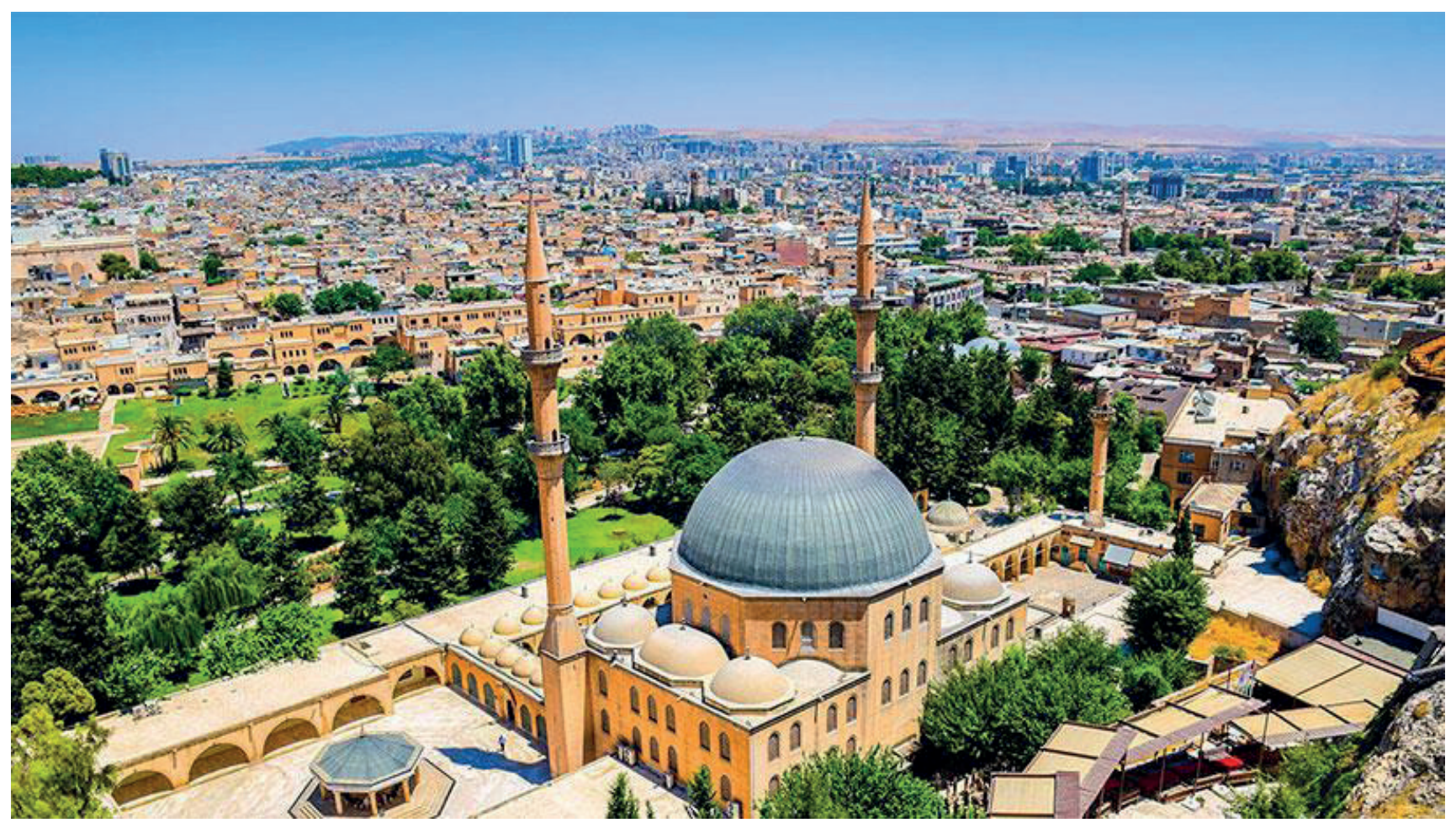

Fotoğraf 1: Eyyübiye İlçe Merkezi'nde Urfa Kalesi'nden Bir Görünüş.

Photo 1: A View from Urfa Castle in Eyyubiye District Center.

Kaynak: https://www.projedefirsat.com/haber/sanliurfada-kentsel-donusum-basliyor

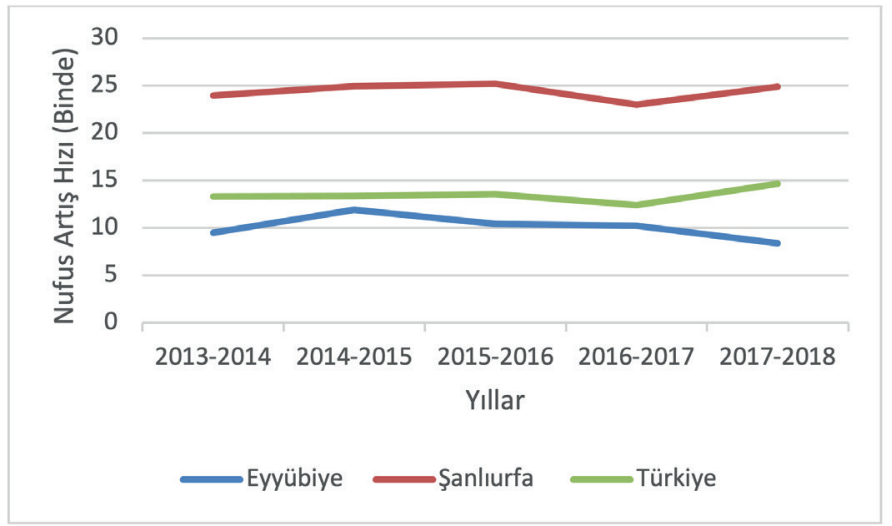

Şekil 4: Türkiye, Şanlıurfa ve Eyyübiye'nin Nüfus Artış Hızı. Figure 4: Population growth rate of Turkey, Şanlıurfa and Eyyubiye. Kaynak: TÜiK, Yıllara Göre illerin Yıllık Nüfus Artış Hızı, 2013-2018.

\subsection{Kentsel Değişime İhtiyaç Duyulan Alanlar}

Gecekondu kavramı, yalnızca izinsiz olarak kamu ya da özel şahıslara ait olan arazilerde yapılan konutlar için değil, şehir konut tiplerine uygun olmayan, kalitesiz ve özensiz olarak inşa edilmiş konutlar için de kullanılmaktadır. Bu açıdan bakıldığında Şanlıurfa şehrinde, çarpık şehirleşmenin ciddi bir sorun olduğu görülmektedir. Bu durum, şehrin fiziksel yapısını ve görünümünü olumsuz yönde etkilemektedir.

Çalışma alanında 39 şehirsel mahallenin 24'ünde kentsel gelişim/değişime ihtiyaç vardır. Bu mahallelerde $12,21 \mathrm{~km}^{2}$ alanda 244.683 kişi yaşamaktadır. Hane sayısı ise TÜIK kayıtlarına göre 39.307'dir. Ortalama hane halkı büyüklüğü 6,22 kişi iken nüfus yoğunluğu km²'ye 20,038 kişi düşmektedir.

\section{BULGULAR VE TARTIŞMA}

\subsection{Geodesign Yöntemi İçin Kullanılan Uygunluk Haritaları}

Geodesign yönteminin internet tabanlı yazılımı olan Geodesign Hub'a (https://www.geodesignhub.com/) yüklemek için 10 farklı uygunluk sistemi oluşturuldu (Tablo 1, Şekil 5). Oluşturulması istenen projelere uygun olabilecek arazileri belirlemek için genel olarak bu sistemler belirlenmiştir.

Her bir sistem için ayrı ayrı kriter belirlenmiş ve bu kriterlere uygun veriler, CBS yazılımlarından biri olan Arcgis ortamında sayısallaştırılmıştır. Daha sonra bu sayısal verilere çakıştırma analizi uygulanıp alt sınıflar belirlenmiştir. Her bir sistem kendi 
Tablo 1: Çalışma için oluşturulan uygunluk haritaları ve kriterleri. Table 1: Suitable maps and criteria created for the study.

\begin{tabular}{|c|c|c|c|}
\hline Uygunluk Haritası & Kriter & Uygunluk Haritası & Kriter \\
\hline Konut Uygunluğu & $\begin{array}{l}\text { Şehir merkezinden uzak olmaması } \\
\text { Dere yataklarına uzaklık }\end{array}$ & Enerji Elektrik Uygunluğu & $\begin{array}{l}\text { Arazi kullanım } \\
\text { Bakı verisi }\end{array}$ \\
\hline & Arazi kullanımı & Endüstri Uygunluğu & Mevcut sanayi tesislerine yakınlık \\
\hline Yeşil Alan (Biyo Koruma) & Arazi kullanımı & & Anayol güzergâhı üstünde \\
\hline Uygunluğu & Mevcut akarsu & & Şehre yakın olması \\
\hline $\begin{array}{l}\text { Su Altyapısı ve Drenaj } \\
\text { Uygunluğu }\end{array}$ & $\begin{array}{l}\text { Dere yatakları } \\
\text { Arazi kullanımı } \\
\text { Parkların büyüklüğü }\end{array}$ & Merkezi İş Alanı Uygunluğu & $\begin{array}{l}\text { Arazi kullanımı } \\
\text { Gün içinde yoğun olarak kullanılan merkezi } \\
\text { mekanlar }\end{array}$ \\
\hline Ulaşım Uygunluğu & $\begin{array}{l}\text { İleride yerleşim açılabilecek potansiyel alanlar, } \\
\text { Sanayi bölgeleri, } \\
\text { Şehirde günlük yaşamda veyahut turizm açısından } \\
\text { önem arz eden merkez noktalar (balıklı göl, şehir } \\
\text { merkezi, üniversite yerleşkesi) }\end{array}$ & Arkeolojik Turizm Uygunluğu & $\begin{array}{l}\text { Nüfus yoğunluğu } \\
\text { Gün içinde yoğun olarak kullanılan merkezi } \\
\text { mekânlar } \\
\text { İleride yerleşmeye açılması düşünülen alanlar } \\
\text { Şehrin turistik merkezleri, }\end{array}$ \\
\hline Tarım Uygunluğu & $\begin{array}{l}\text { Arazi kullanımı } \\
\text { Arazi eğim }\end{array}$ & & $\begin{array}{l}\text { Doğal ve arkeolojik sit alanları } \\
\text { Arazinin eğim derecesi }\end{array}$ \\
\hline
\end{tabular}

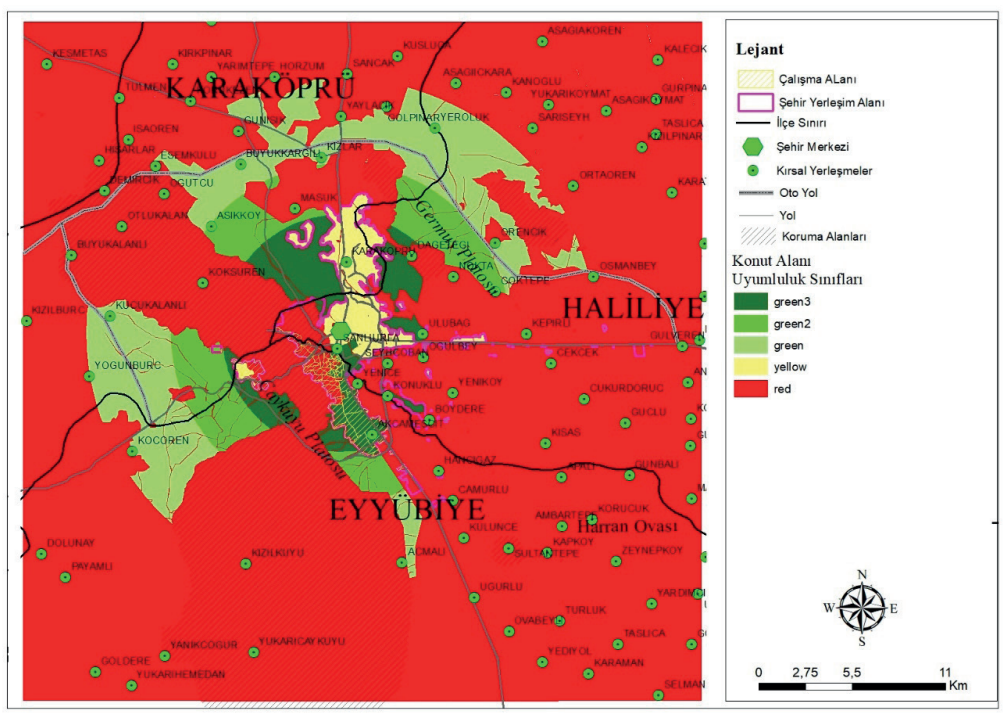

a) Konut Uygunluk Haritas1

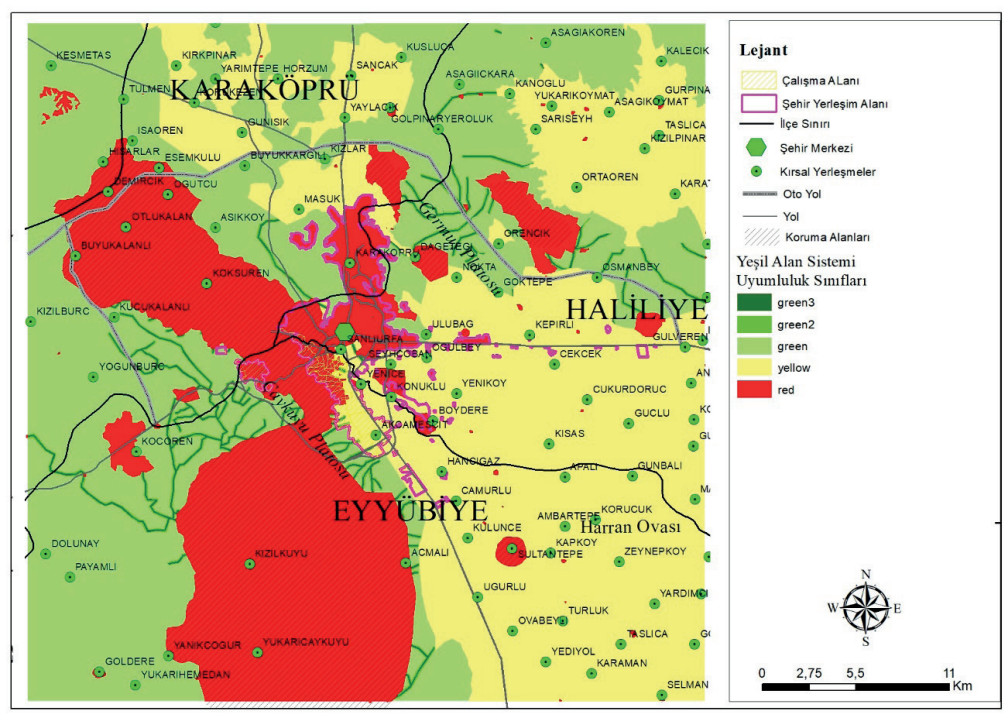

b) Yeşil Alan (Biyo Koruma) Uygunluk Haritası 


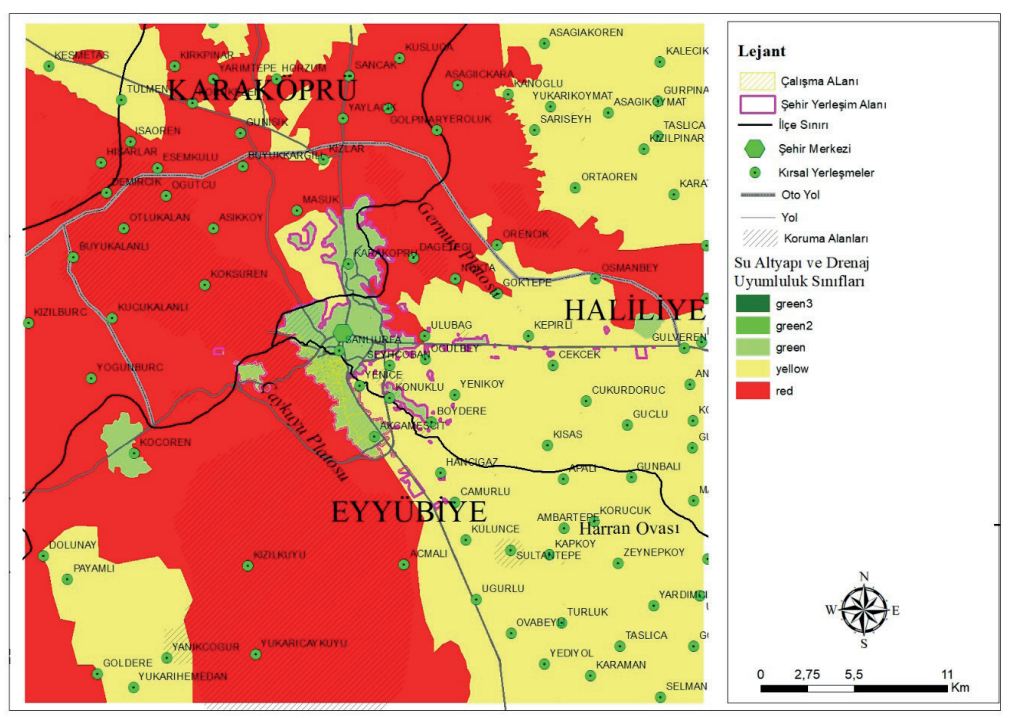

c) Su Altyapısı ve Drenaj Uygunluk Haritası
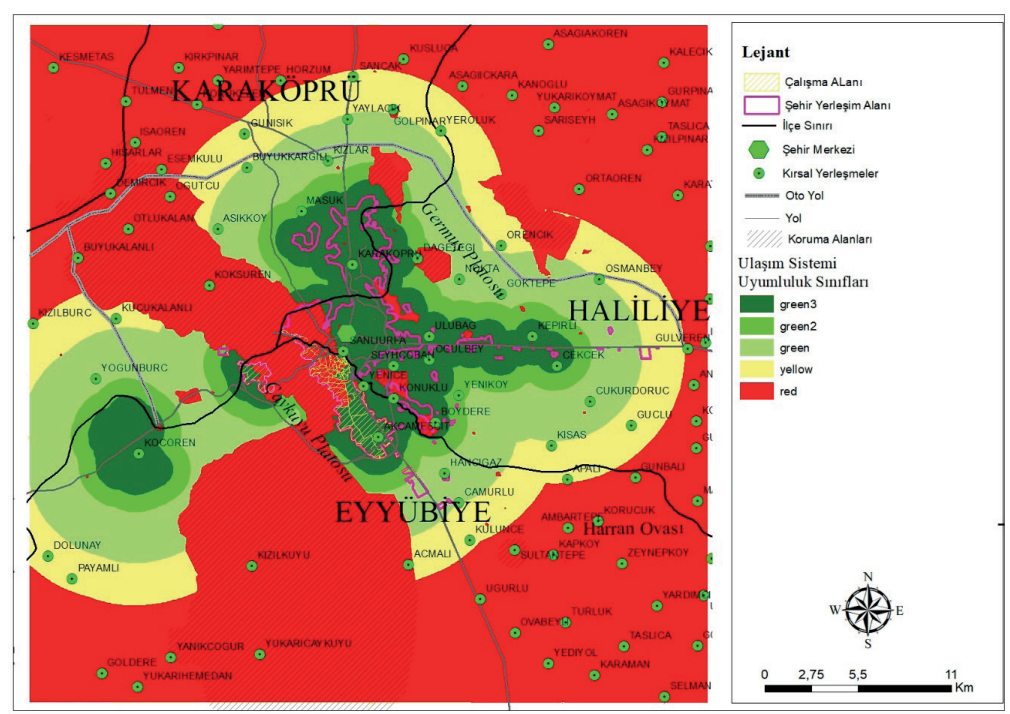

d) Ulaşım Uygunluk Haritası

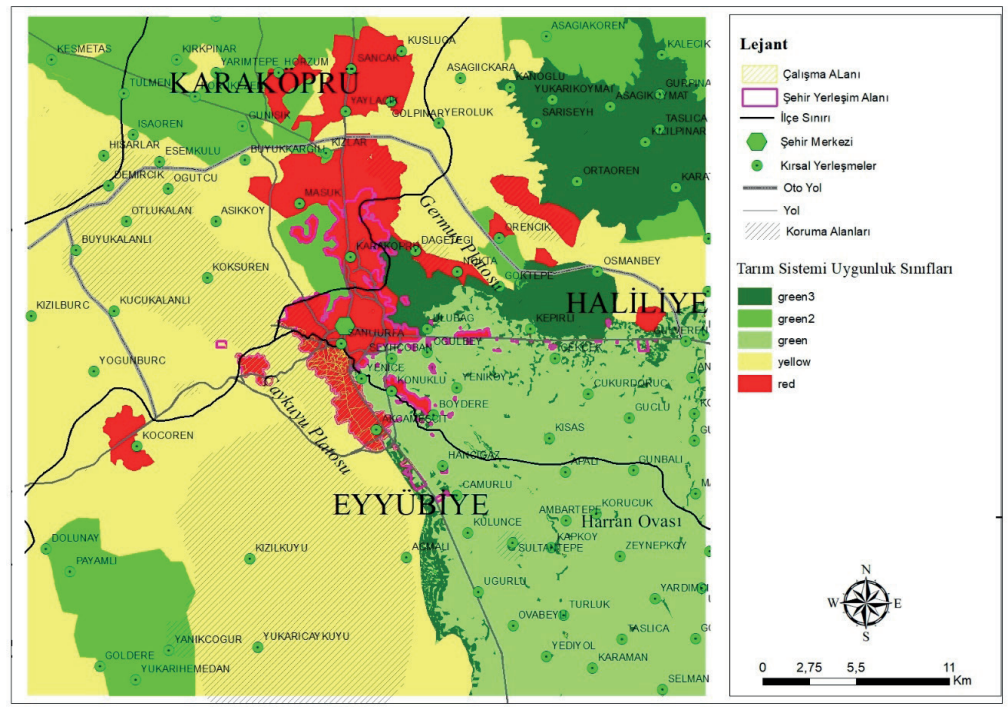

e) Tarım Uygunluk Haritas1 


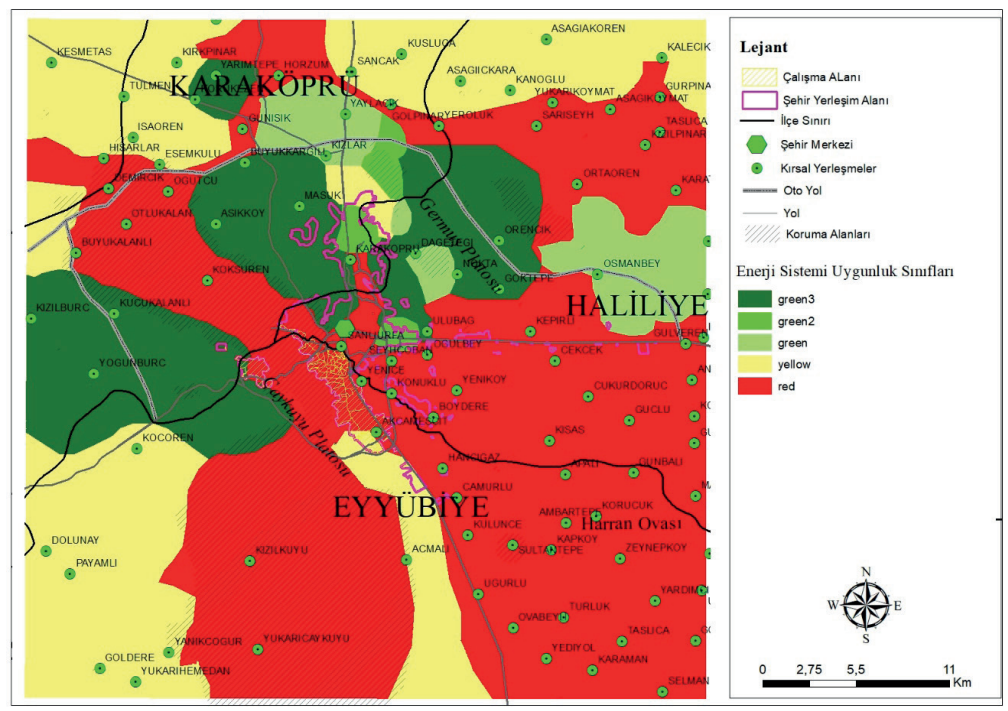

f) Enerji/ Elektrik Uygunluk Haritası

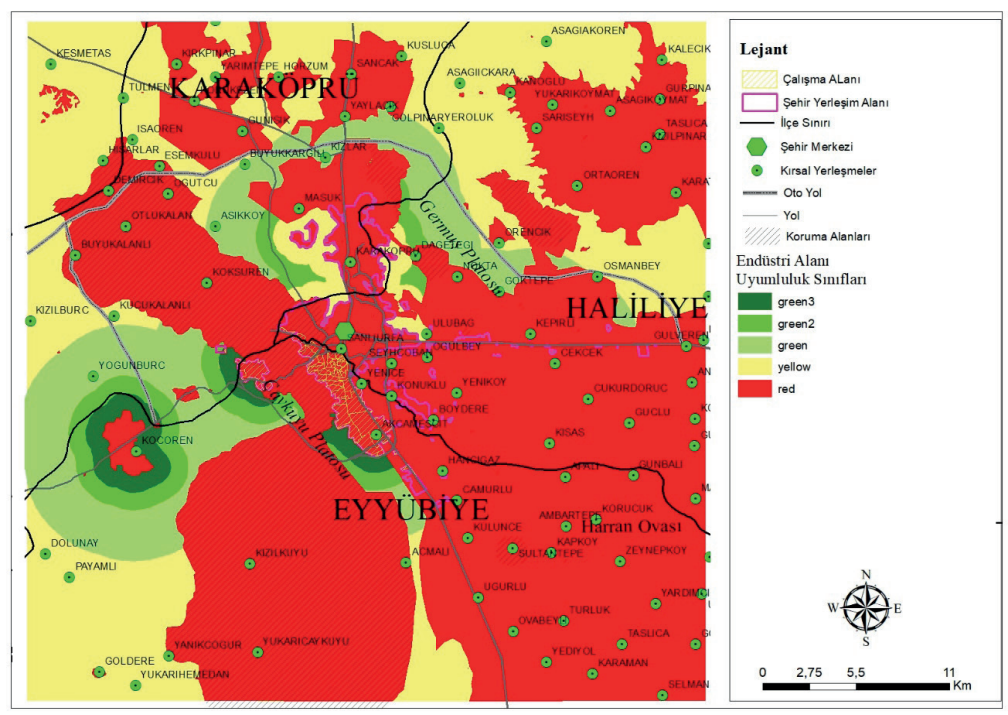

g) Endüstri Uygunluk Haritas1

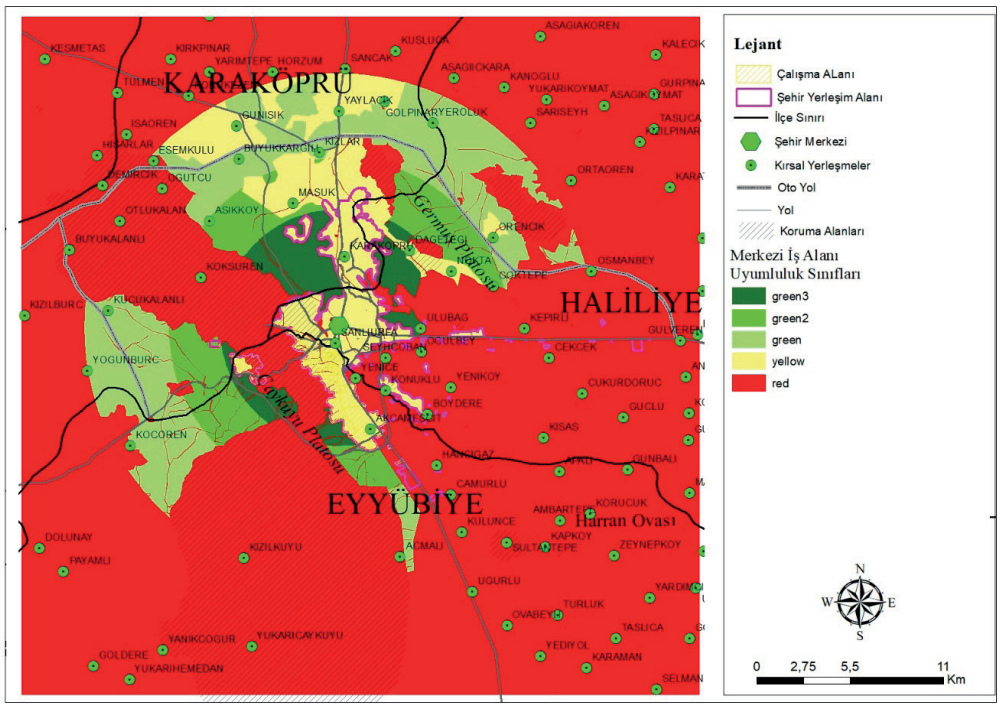

h) Merkezi İş Alanı Uygunluk Haritası 


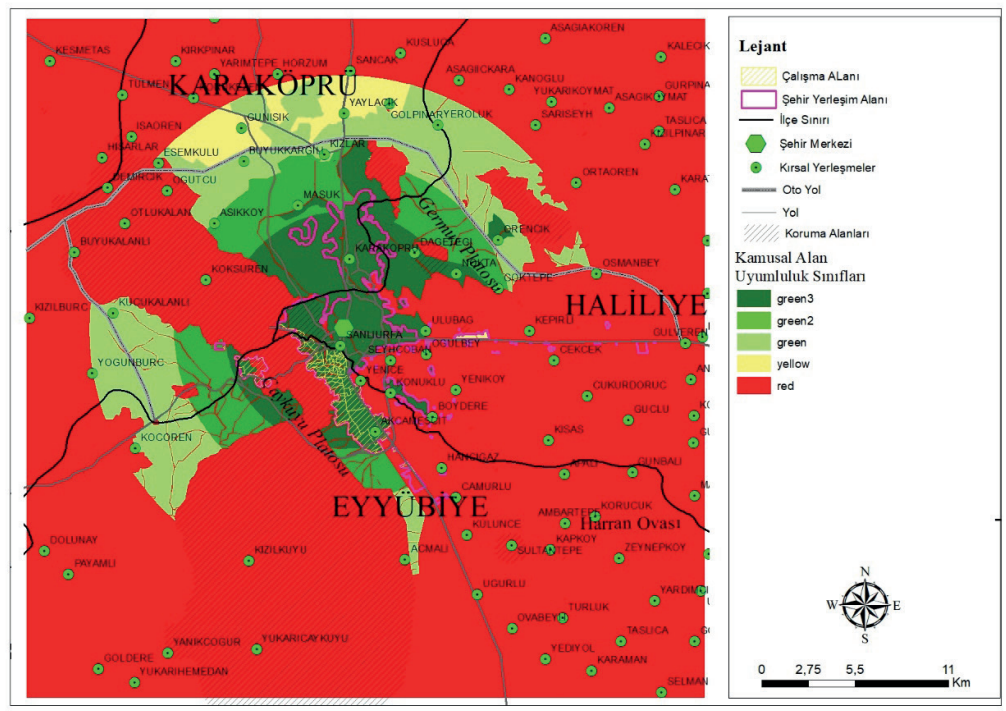

i) Kamusal Alan Uygunluk Haritas1

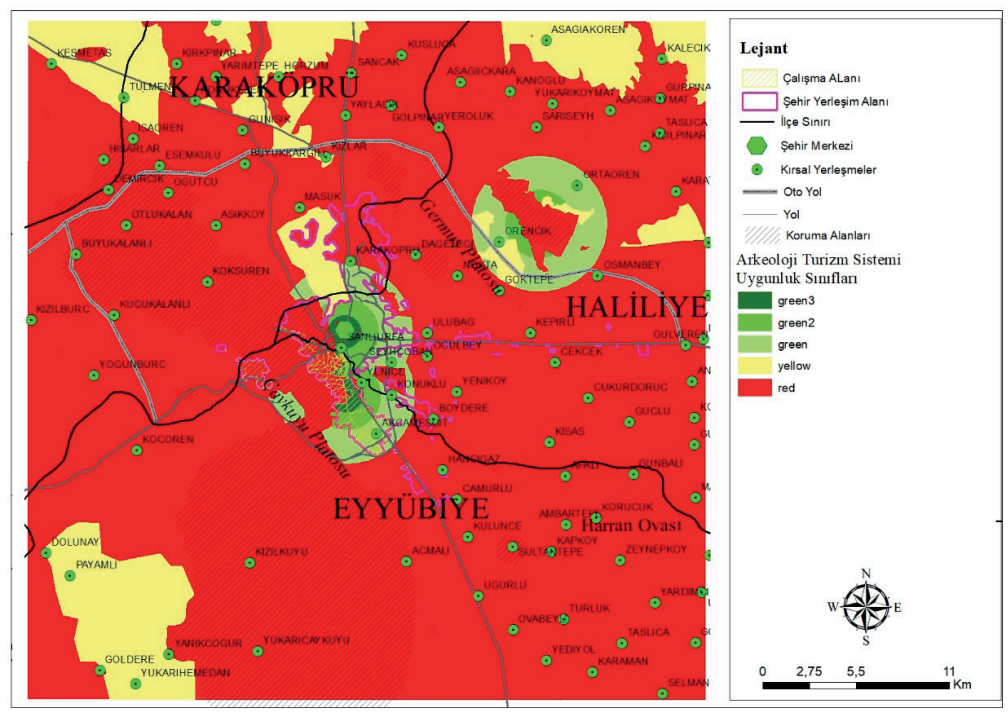

j) Arkeolojik Turizm Uygunluk Haritas1

Şekil 5: Geodesign Hub İçin Oluşturulan Uygunluk Haritaları. Figure 5: Suitable maps created for Geodesign Hub.

içinde 5 sınıftan oluşmuş ve her bir sınıf bir renk ile ifade edilmiştir. Bu sistemler ve sınıflandırma uzman görüşleri ve literatür taraması sonucu belirlenmiştir. Buna göre, renklere dayalı sınıflandırma sistemleri ve anlamları şu şekilde gruplandırılabilir:

* Green3 en uygun sınıfı ifade etmektedir. Bir proje için uygun alan belirlenecek ise koyu yeşil sınıfına giren alanlar öncelik olarak tercih edilmelidir.

* Green2 orta derecede uygun sinifi ifade etmektedir. Bir proje için uygun alan belirlenecek ise birinci sınıfa giren alanlar bittikten sonra bu sinıfa giren alanlar tercih edilmelidir.
Green üçüncü sınıfı ifade etmektedir. Bir proje için uygun alan belirlenecek ise birinci ve ikinci sınıfa giren alanlar bittikten sonra bu sinıfa giren alanlar tercih edilmelidir.

* Yellow uygun olamayan alanları ifade etmektedir. Bir proje için uygun alan belirlenecek ise sarı ile gösterilen alanlar proje için uygun alan olmadığını ifade etmektedir.

* Red ise, kırmızı ile gösterilen alanlar iki durumu göstermektedir. İlk durum bu alanlara müdahale edilmemesi gerektiğini bildirir. İkinci durum ise yapılması istenen proje bu alanda mevcut olduğunu bildirir. 
$\mathrm{Bu} 10$ sistem farklı mekanlarda çalışılmak istense içeriği değiştirilebilir, fakat belirlenen 5 sinıf ve renkleri Geodesign Hub yazılımı için standart olmalıdır. Aksi takdirde yazılım, bu sistemleri tanımlayamaz.

\subsection{Alternatif Plan ve Senaryolar (Change Models ve Impact Models)}

\subsubsection{Normal Gelişim Senaryosu Sonucu Yerleşim} Alanlarının İncelenmesi

Çalışma alanı, jeomorfolojik olarak ova ile plato arasındaki geçiş kuşağ 1 olan yamaç üzerinde kurulan ve gelişen yerleşmelerdir. Bu yerleşmeler ovalık alana doğru ilerlemekte ve tarım yapılması gereken alanları ortadan kaldırmaktadır. Tarım alanlarında insanlar bina inşa edilirken, yapı maliyetini azaltmak için sert yüzeyler yerine daha yumuşak toprak yüzeylerini tercih etmeleri ayrıca bir sorun teşkil etmektedir. Halkın dışında kamu kurum ve kuruşları tarafından yaptırılan kamu binaları ve yollar da tarım alanlarını işgal etmektedir. Örneğin Eyyübiye devlet hastanesi ovalık alan üzerinde kurulmuştur. Hastane çevresi ile 10 hektarlık bir araziyi işgal etmiştir. Ayrıca bu hastane için yapılmış olan çevre yolu tarım alanlarının içerisinden geçmektedir. Yolun tarım alanlarından geçirilmesi tarım yapılması gereken alanları amaç dışı kullanılarak zarar vermesinin yanında bu yolun çevresinde yeni iş yerleri inşa edilerek daha fazla tarım alanı tahrip edilmektedir (Şekil 6).

Çevre yolu güzergahı üzerinde bulunan ve merkeze yakın mesafede olan Konuklu beldesine imar verilmesiyle hizlıca tarım alanları içerisinde binalar inşa edilmeye başlanmıştır. Şehir planlamasında tarım alanlarına dikkat edilmezse yakın zamanda beldenin şehrin yerleșim alanları ile birleşmesi kaçınılmazdır. Bunun sonuncunda da tarım alanlarının geri dönüşümü olmadan tahrip olması kaçınılmazdır (Şekil 6). Bundan dolayı normal gelişim senaryosu olarak belirlenen bu senaryoda yerleşme amaçlı kullanılabilecek alanlar Geodesign Hub'da incelenmiştir (Şekil 7).

Geodesign Hub'da normal gelişim senaryosunun konut sistemi için çapraz etki analizi haritası incelendiğinde, tarım alanları üzerinde yapılacak konut alanları "Most Negatif Impact" olarak görülmektedir. Yalnızca planlanan alanların güney kısmına denk gelen alanlarda "Most Positive Impact" olarak görülmektedir. $\mathrm{Bu}$ inceleme soncunda, söz konusu alanların konut sistemi çapraz etki analizi haritasında kötü etkiye sahip olduğu anlaşılmıştır. $\mathrm{Bu}$ alanların tarım için kullanılması gerekmektedir. Şehrin gelişim yönüne dikkat edilmez ise daha fazla tarım alanı işgal edilecektir (Şekil 7).

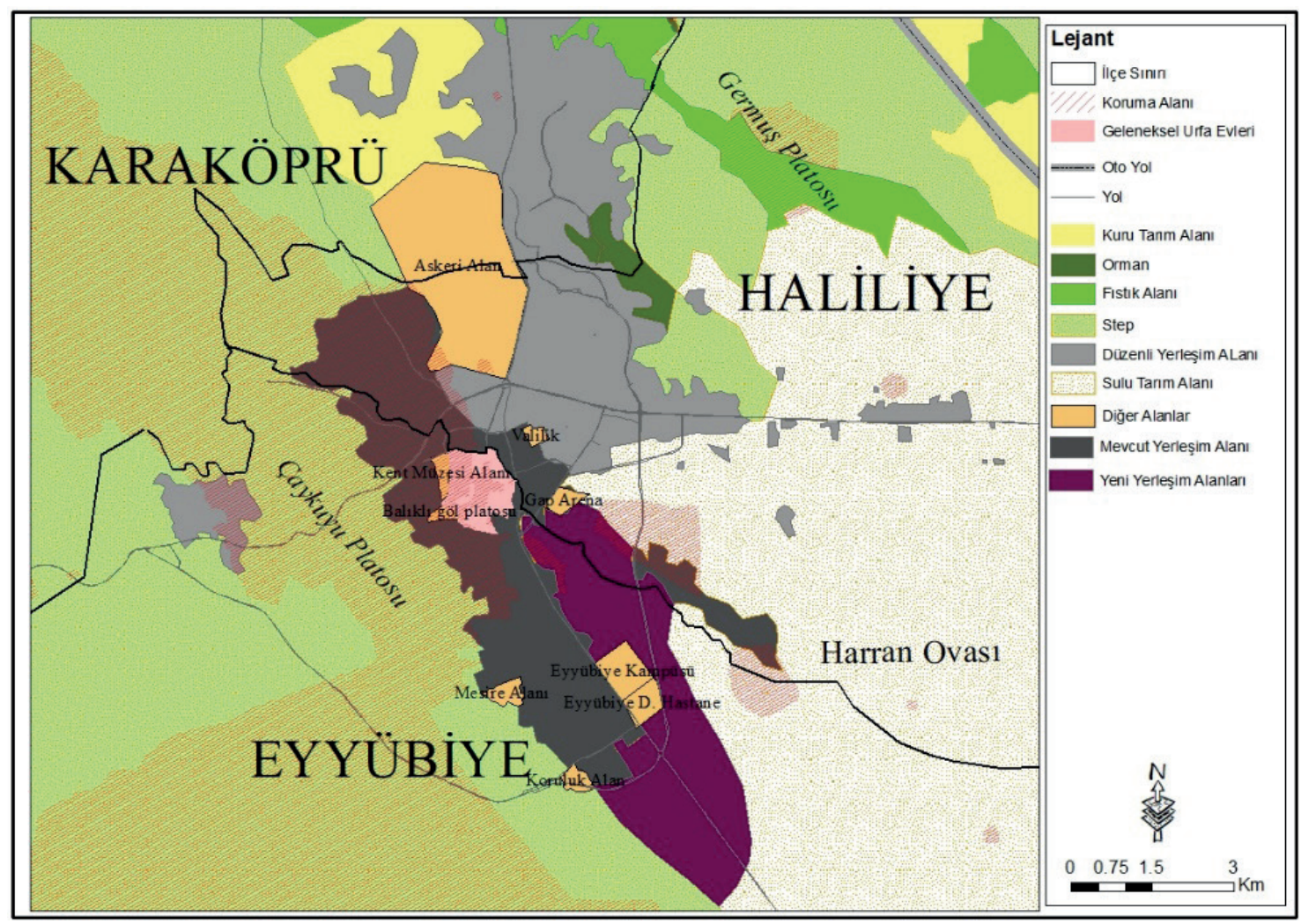

Şekil 6: Normal Gelişim Senaryosu.

Figure 6: Ordinary Development Scenario. 


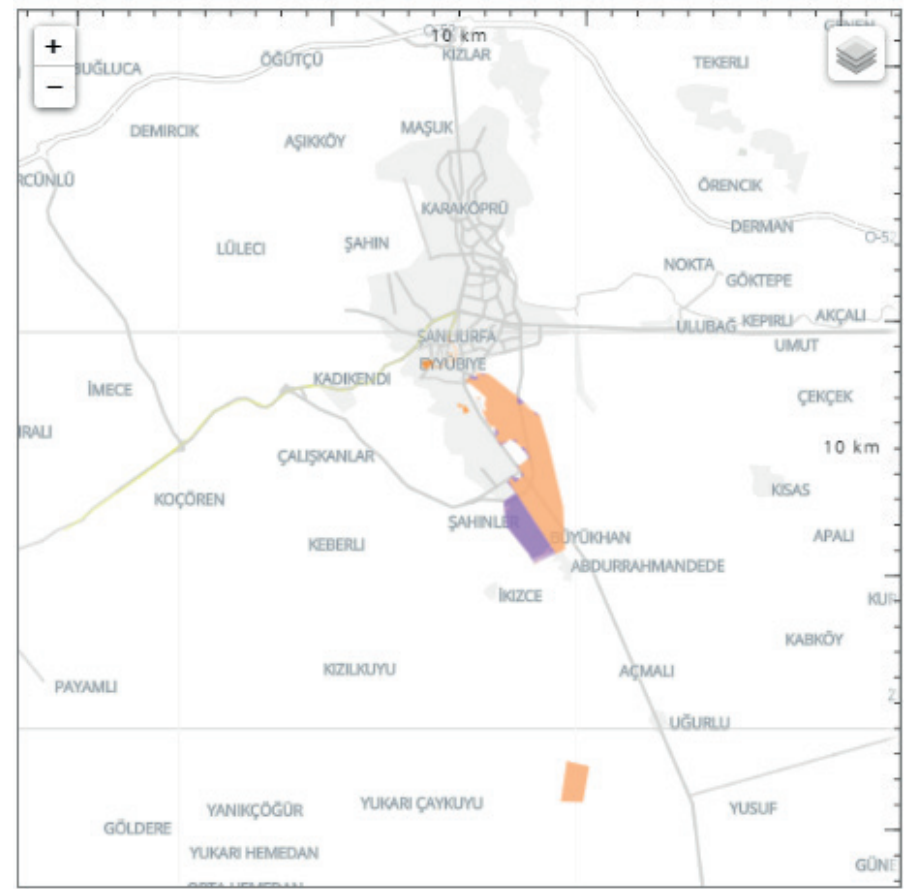

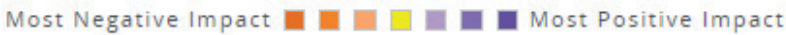

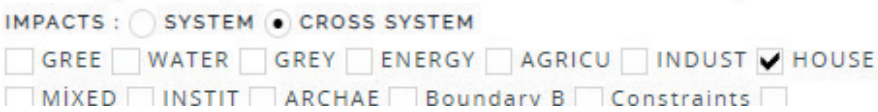

Şekil 7: Geodesign Hub'da Normal Gelişim Senaryosunun Konut Sistemi Çapraz Etki Analizi

Figure 7: Housing System Cross Impact Analysis of Ordinary Development Scenario in Geodesign Hub.

\subsubsection{Düzenli Yerleşim Alanları Planlama Çalışması}

Kentsel Değişime İhtiyaç Duyulan Alanlar başlığı altında 39 şehirsel mahallenin 24'ünde kentsel gelişim/değişime ihtiyaç olduğu belirtilmiştir. $\mathrm{Bu}$ mahallelerin yüz ölçümü toplamda 12,21 km² dir. Bu mahallelerde 244.683 kişi yaşamaktadır. TÜİK kayıtlarına göre bu alanlarda 39.307 hane bulunmaktadır. Ortalama hane halkı büyüklüğü 6,22 kişi, $\mathrm{km}^{2}$ ye 20.038 kişi düşmektedir. Bu 24 mahallenin 15 mahallesi ise DSİ tarafından Balıklı Gölü besleyen havzayı koruma alanı içerisine girdiğinden 4,31 $\mathrm{km}^{2}$ lik bu alanlar tekrar yerleşme amaçlı kullanılması uygun değildir (Fotoğraf 2).

$\mathrm{Bu}$ gelişim senaryosu için ortalama hane halkı 4 olarak belirlendiğinde 244.683 kişi için 61.171 yeni konuta ihtiyaç duyulmaktadır. Planlanan yeni konutlar $250 \mathrm{~m}^{2}$ alan üzerinde, 5 katlı bir bina içerisinde 40 kişi yaşayabileceği düşünülerek 2035 yılı için hesaplama yapılmıştır. Bu konutlar için $15.292 .750 \mathrm{~m}^{2}$ yani $15,30 \mathrm{~km}^{2}$ konut için yerleşim alanına ihtiyaç duyulacaktır.

Çalışma alanı içerisinde kişi başına düşen yeşil alan oldukça azdır. Nitekim WHO tarafından bir kentte kişi başına düşen yeşil alan miktarının en az $9 \mathrm{~m}^{2}$ olması gerektiğini ancak bunun idealinin 10-15 m² olduğu belirtmiştir (Benek ve Şahap, 2017). $\mathrm{Bu}$ kriterden hareketle bu insanlar için ortalama olarak kişi başı

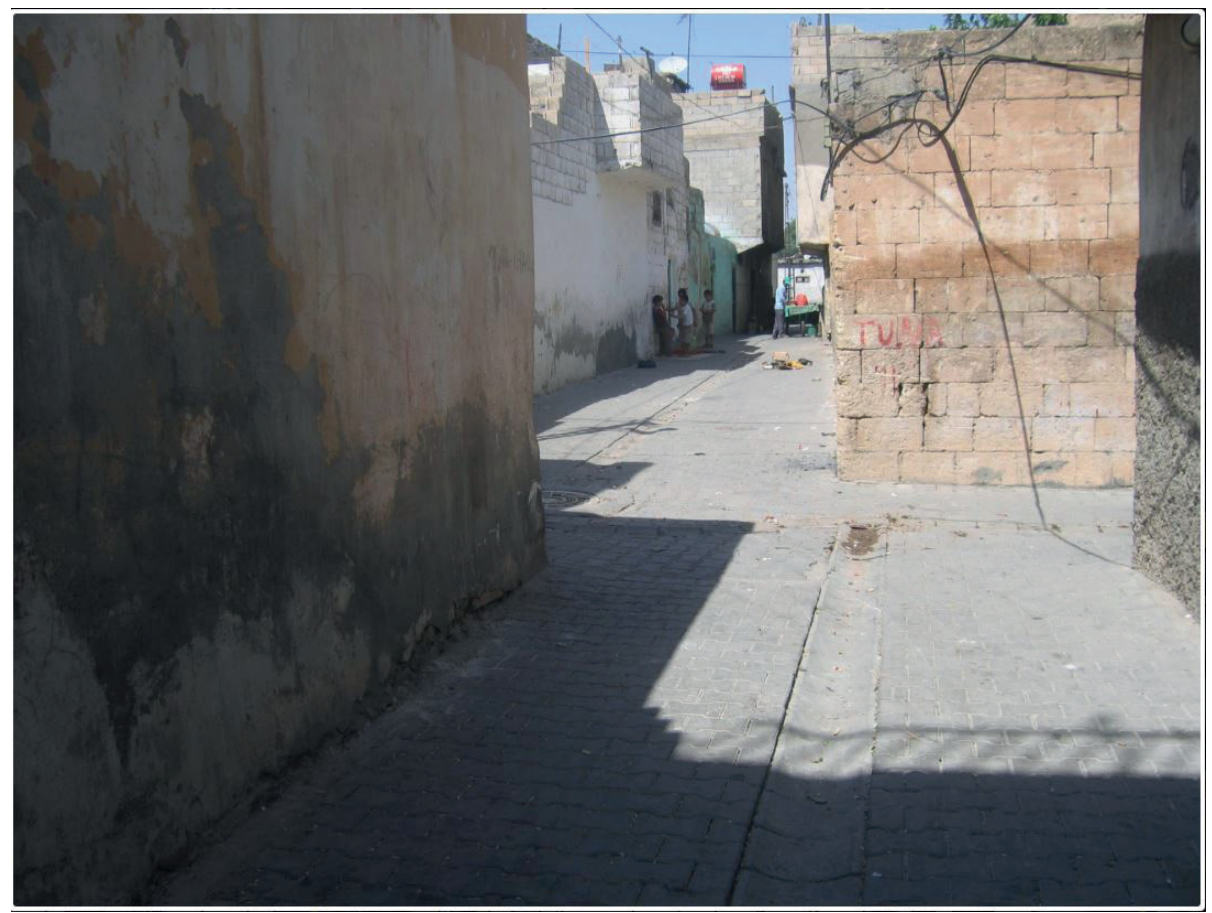

Fotoğraf 2: Kentsel Dönüşüme İhtiyaç Duyulan Mahallelerden Bir Olan Onikiler Mahallesinden Bir Görünüm. Photo 2: A View from the Onikiler Neighborhoods, One of the Neighborhoods Where Urban Transformation Is Needed. 


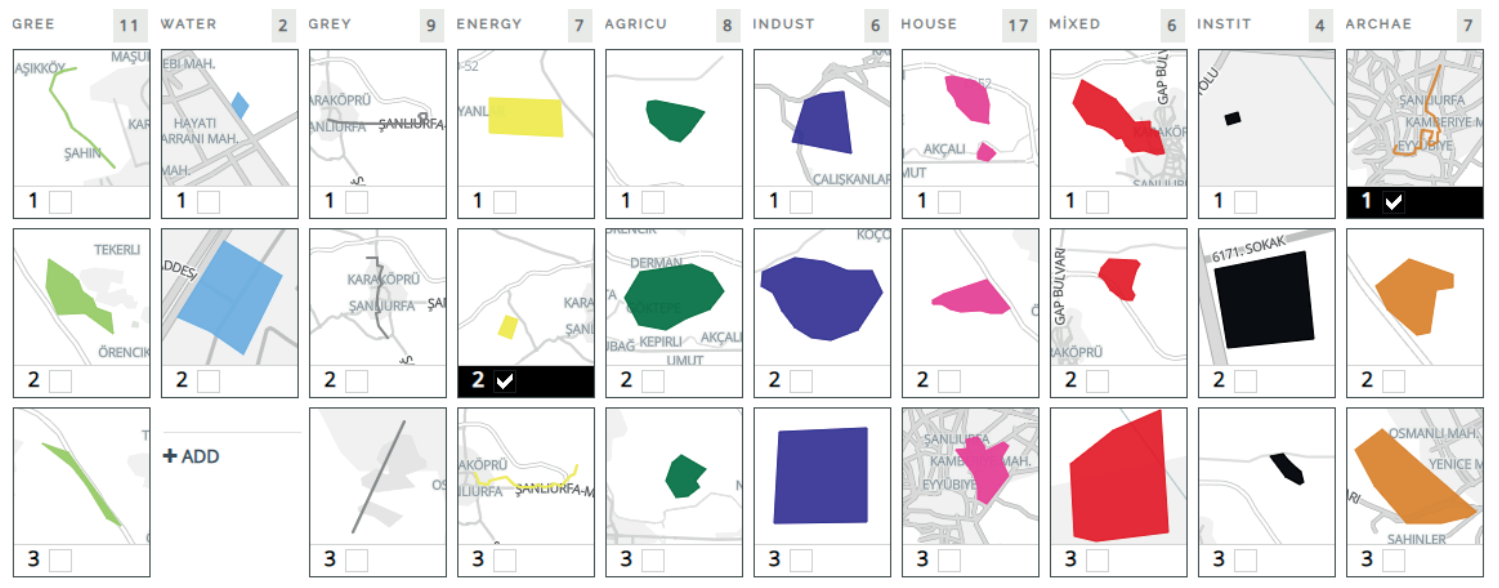

Şekil 8: Geodesign Hub Yazılımında Örnek Tasarlanan Alanlar (Change models).

Figure 8: Sample Designed Fields in Geodesign Hub Software (Change models).

$10 \mathrm{~m}^{2}$ yeşil alan için $2,45 \mathrm{~km}^{2}$ yeşil alana ihtiyaç duyulmaktadır. Konut ve yeşil alan için toplam $17,75 \mathrm{~km}^{2}$ yerleşme alanına ihtiyaç vardır.

Yerleşim alanları zamanla gerek yeni doğumlar gerekse çevresinden göç alarak büyüme göstermektedir. 2018 yılında 276.354 kişi ve nüfus artış hızı binde 24,9 olarak hesaplanan ilçe nüfusu 2035 yılında 160.210 kişi artarak 404.893 kişi olacağ1 tahmin edilmektedir (Çullu vd. 2019). 2035 yılına kadar 40.053 yeni konuta ve 10.013.250 $\mathrm{m}^{2}$ yani $10,01 \mathrm{~km}^{2}$ yerleşim alanına ihtiyaç duyulmaktadır. Yeşil alan için ise $1,60 \mathrm{~km}^{2}$ alana ihtiyaç duyulmaktadır. Konut ve yeşil alan için ise toplam $16,61 \mathrm{~km}^{2}$ yerleşim alanına ihtiyaç duyulmaktadır.

Eyyübiye ilçesi şehirsel alanda bulunan yerleşmeler için Geodesign yöntemine göre yapılan yerleşim alanlarının tespit analizleri sonucu düzenlenmesi veya geliştirilmesi gereken alanlar 12,21 km² olarak tespit edilmiştir. Bu alanın $7.61 \mathrm{~km}^{2}$ lik kısmı, yani 9 mahalle yerleşmesi, öncelikli düzenlenmesi veya geliştirilmesi gereken yerleşim alanı olarak tespit edilmiştir. $\mathrm{Bu}$ yerleşim alanları Eyyübiye ilçesi şehirsel alanda bulunan yerleşme alanlarının güney kesimine tekabül etmektedir. Ayrıca, Eyyübiye ilçesi şehirsel alanda bulunan yerleşmelerin 4.13 $\mathrm{km}^{2}$ 'lik diğer kısmı ise daha önce belirtildiği gibi Balıklı Göl'ü besleyen yeraltı su havzasını korumak için yasal koruma altına alınmıştır. Bu koruma alanı içerisinde bulunan 15 mahalle yerleşim alanı tekrar yerleşime açmak yerine rekreasyon alanlarına dönüştürülebilir.

Bu senaryo için belirlenen tasarım alanları; $1,36 \mathrm{~km}^{2}$ güneş enerji santrali, 1,34 $\mathrm{km}^{2}$ kentsel atık alanı, ormanlık alan, turizm alanları, OSB - şehir merkezine bağlantı kuracak hafif raylı sistemi, Geleneksel Urfa Evleri'nin arasından Balıklı Göl'e kadar yürüyerek şehrin tarihi alanlarını gezebilmek için Turizm yolu, Balıklı Göl ve çevresinde rekreasyon alanı, Hz. Eyüp peygamber makamı ve çevresinde rekreasyon alanıdır (Şekil 8).

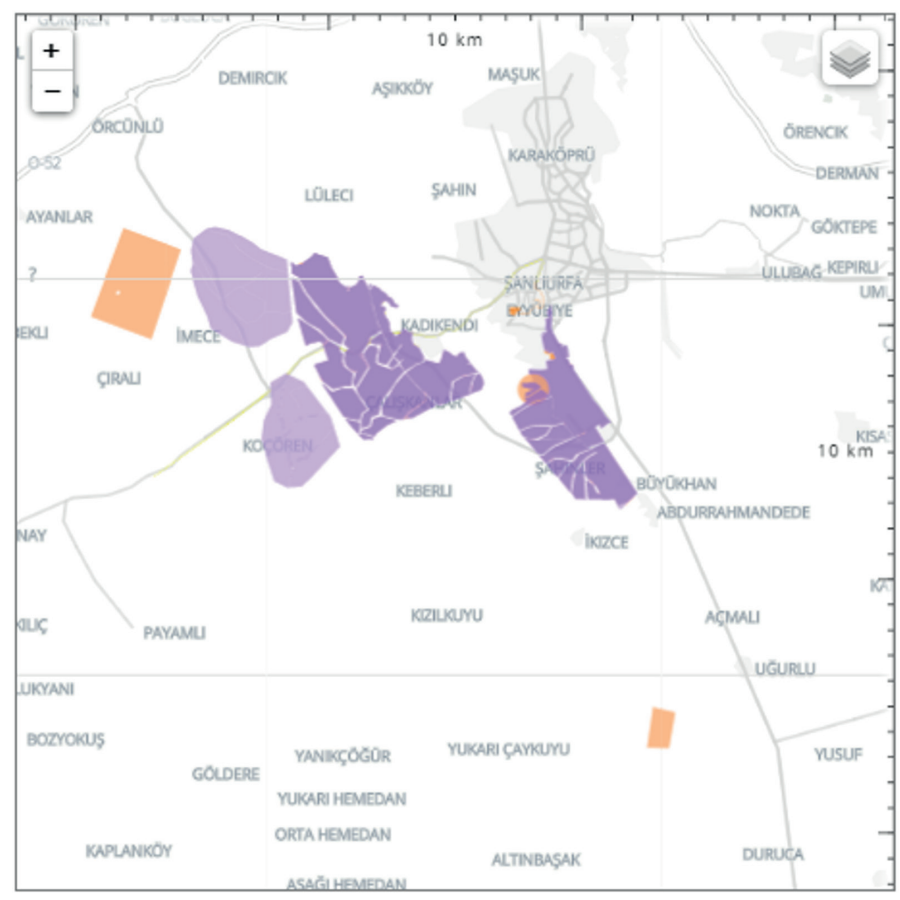

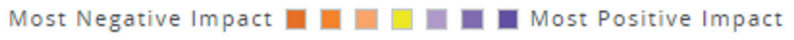

IMPACTS: SYSTEM $\bullet$ CROSS SYSTEM

$\square$ GRee $\square$ Water $\square$ GRey $\square$ energy $\square$ agricu $\square$ Indust $\checkmark$ HOUSE

MIXED $\square$ INSTIT $\square$ ARCHAE $\square$ Boundary B $\square$ Constraints

Boundary A

Şekil 9: Geodesign Hub' da Düzenli Yerleşim Alanları Konut Sistemi Çapraz Etki Analizi

Figure 9: Regular Settlements in the Geodesign Hub Housing System Cross Impact Analysis. 
$\mathrm{Bu}$ yerleşim alanlarının konut ve tarım sistemi ile etkisi incelendiğinde pozitif etkiye sahip olduğu anlaşılmıştır. Belirlenen bu yerleşim alanlarının çapraz etki analizine bakıldığında konut etki analizi pozitif iken tarım etki analizi de mevcut yerleşim alanları için pozitif, diğer alanlar ise nötrdür (Şekil 9; Şekil 10).

Eyyübiye ilçesinde bulunan kentsel gelişim ve değişime ihtiyaç duyulan yerleşmelerin 20.038 kişi/ $\mathrm{km}^{2}$ olan nüfus yoğunluğu çok yüksektir. Ayrıca bu yerleşmelerin 6,22 olan ortalama hane halkı yoğunluğu Türkiye ortalamasının çok üzerindedir. Bu yüksek oranları düşürmek için 244.683 kişinin ihtiyaç duyduğu 61.171 yeni konut için gerekli olan $17,75 \mathrm{~km}^{2}$ konut ve yeşil alan amaçlı yerleşimalanına ihtiyaç duyulmaktadır. $\mathrm{Bu}$ yerleşim alanları için öncelikli düzenlemesi gereken 7,61 $\mathrm{km}^{2}$ yerleşim alanı ve öncelikli yerleşime açılması gereken 15 $\mathrm{km}^{2}$ alanın toplamı yani 22,61 km² lik bir alanla karşılanabilir. $\mathrm{Bu}$ yeni alan yerleşime açılır ise nüfus yoğunluğunun da düşmesi kaçınılmazdır (Tablo 2; Şekil 11).

Tablo 2: Düzenli Yerleşim Alanları İçin Tasarlanan Arazi Miktarı. Table 2: Amount of Land Designed for Regular Settlements.

\begin{tabular}{lc}
\hline Alan & $\mathbf{K m}^{\mathbf{2}}$ \\
\hline Öncelikli Düzenlemesi Gereken Yerleşim Alanı & 7.61 \\
Öncelikli Yerleşime Açılması Gereken Alan & 15 \\
İinci Derecede Yerleşime Açılması Gereken Alan & 19 \\
Yerleşme Açılabilir Toplam Alan & $\mathbf{4 1 , 6 1}$ \\
\hline
\end{tabular}

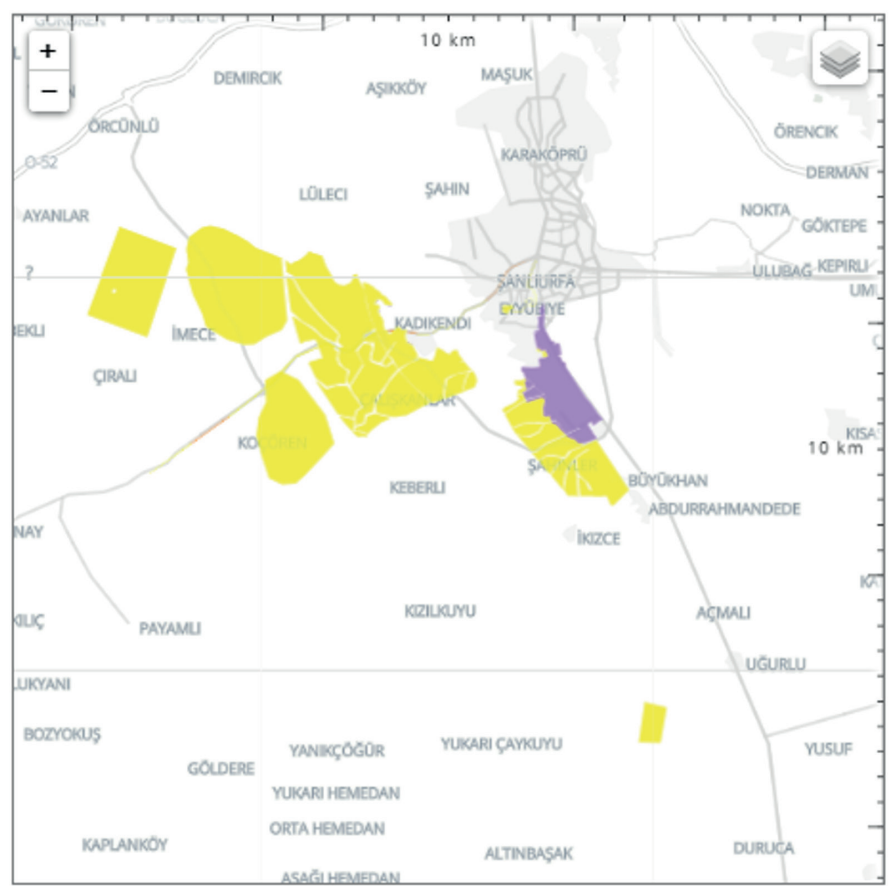

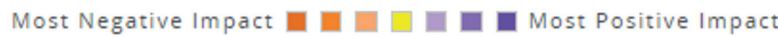

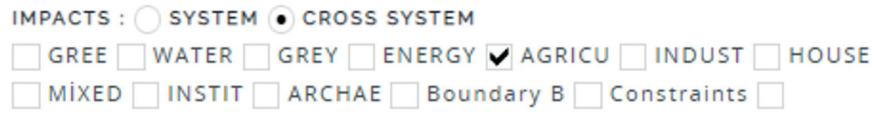

Şekil 10: Geodesign Hub'da Düzenli Yerleşim Alanları Tarım Sistemi Çapraz Etki Analizi

Figure 10: Regular Settlements Agricultural System Cross Impact Analysis in the Geodesign Hub.

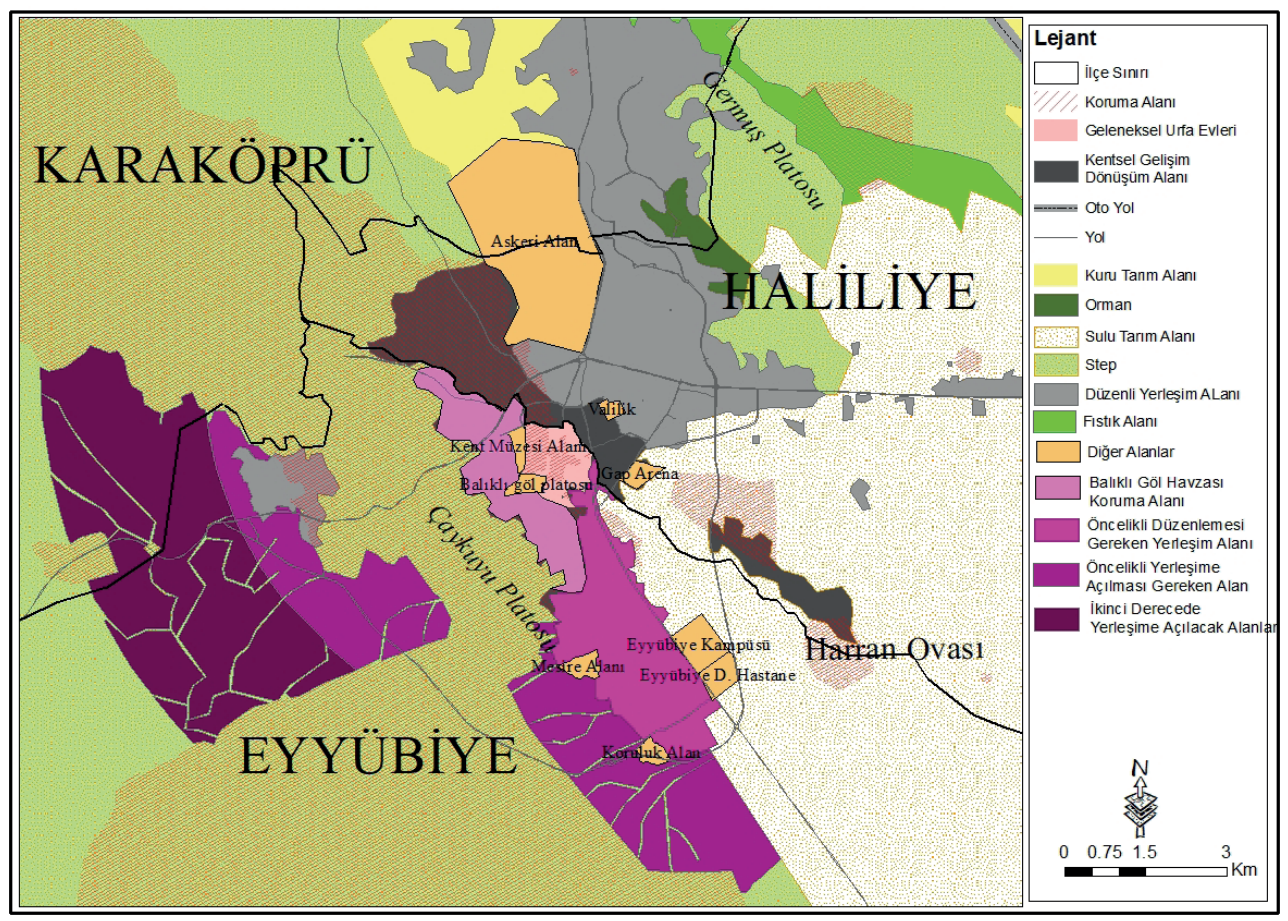

Şekil 11: Düzenli Yerleşim Senaryosu

Figure 11: Regular Settlements Scenario. 


\section{SONUÇ}

Şanlıurfa bir taraftan kırdan kente göç, diğer taraftan da Suriye'deki iç savaştan kaçan insanların oluşturduğu kitlesel göçten nasibini almıştır. Şanlıurfa'da, hızlı nüfus artışıyla birlikte diğer pek çok şehirdeki gibi, çarpık kentleşme ve gecekondular ortaya çıkmıştır. Şehrin kaldırabileceğinden daha fazla nüfusa ev sahipliği yapmaya başlaması, şehrin insani açıdan yaşana bilirliğini de tartışma konusu yapmıştır. Özellikle de son yıllardaki, hızlı nüfus artışı ve kitlesel göç, beraberinde insanları, sosyoekonomik faaliyetleri sürdürmek için yeni mekân arayışlarına ve bu mekânları şekillendirerek yeni yapılar inşa etmeye yöneltmiştir. Bu yerleşim birimleri özellikle az gelirli bölgelerde gecekondu yapıları meydana getirerek çarpık kentleşmeye neden olmuştur. Bu sebeplerden dolayı bu çalışma, Şanlıurfa şehrinde benzer özellikte bir şehirleşmeye sahip olan 276.352 nüfuslu, 17,453 ( $\mathrm{km}^{2} /$ kişi) nüfus yoğunluklu ve 15,85 $\mathrm{km}^{2}$ alana sahip Eyyübiye ilçe merkezi örneği üzerinden kentsel dönüşüm projeleri için doğal ortam özellikleri ile insanların sosyoekonomik durumlarına uygun yaşanılabilir bir kent inşa etmek için kentsel gelişime/değişime ilişkin bazı önerilerde bulunmak üzere hazırlanmıştır. Eyyübiye ilçesi Şanlıurfa ilindeki en fazla nüfusa sahip ilçedir. Şehirsel alanda kalan mahallelerdeki nüfusun; 0-14 yaş arasında 113.771 kişi, 15-64 yaş arasında 152.834 kişi, 65 yaş üstü ise 9.749 kişidir. Şehirsel alanda kalan mahallelerdeki bağımlı nüfus oranı ciddi bir düzeydedir $(\% 44,69)$. İlçenin bağılı nüfusu, ilçe nüfusunun hemen hemen yarısı kadardır. Eyyübiye ilçesinde, 2014 yılı doğurganlık hızı 5,26 iken, 2018 yılında \%4,81 ile Şanlıurfa ve Türkiye ortalamasının üzerindedir. Eyyübiye ilçesinde 2018 y1lında nüfusun \%3,46's1 kadar bebek dünyaya gelirken, nüfusun $\% 0,30$ 'ü kadar insan vefat etmiştir. Nüfus artış hızına bakıldığında $\% 44,4$ ile ilin ve Türkiye ortalamasının altında olması ilçenin göç verdiğini göstermektedir. Bir yer tasarımı olan Geodesign yöntemi ile şehrin doğal ortam ile ilişkisini göz önüne alınarak, şehrin gelişimi, nüfus artış oranları ile ihtiyaç duyulabilecek yeni kentsel gelişim alanlarının mümkün olabileceği anlaşılmaktadır.

Çalışma alanı jeomorfolojik olarak ova ile plato arasındaki geçiş kuşağı olan yamaç üzerinde kurulmuş ve gelişmektedir. Bu yerleşmeler, ovalık alana doğru ilerlemekte ve tarım yapılması gereken alanları ortadan kaldırmaktadır. Tarım alanlarını insanların bina inşa edilirken yapı maliyetini azaltmak için sert yüzeyler yerine daha yumuşak toprak yüzeylerini tercih etmeleri ayrıca bir sorun teşkil etmektedir. Halkın dışında kamu kurum ve kuruşları tarafından yaptırılan binaların ve yolların yanlış yer seçiminden kaynaklı tarım alanları işgal edilmektedir. Örnek olarak Eyyübiye Devlet Hastahanesi, ovalık alan üzerinde kurulmuş olup, hastane çevresi ile beraber 10 hektarlık bir arazi işgal edilmiştir. Ayrıca ovalık alan içinde ve merkeze yakın mesafede olan Konuklu beldesine imar verilmesi ile hızlıca tarım alanlarının içine binalar yapılmaktadır.

Netice itibariyle, 39 şehirsel mahallenin oluşturduğu Eyyübiye ilçesindeki toplam yüz ölçümü $12,21 \mathrm{~km}^{2}$, toplam nüfusunun 244.683 kişi ve 39.307 hanenin bulunduğu, 15 Temmuz, Akabe, Akșemsettin, Buhara, Dedeosman, Direkli, Eyüpkent, Eyyup Nebi, Eyyübiye, Hacıbayram, Haleplibahçe, Hayati Harrani, Karakoyunlu, Mance, Muradiye, Onikiler, Osmanlı, Ruha, Selçuklu, Süleymanşah, Şıh Maksut, Topdağı, Yakubiye, Yenice mahalleleri başta olmak üzere, 39 mahallenin 24'ünün tamamında kentsel gelişim/değişime ihtiyacı olduğu saptanmıştır. Ortalama hane halkı büyüklüğünün 6,22 kişinin olduğu, $\mathrm{km}^{2}$ ye $20.038,34$ kişinin düştüğü bu yerleşim alanları için öncelikli düzenlemesi gereken $7,89 \mathrm{~km}^{2}$ yerleşim alanı ve yerleşime açılması gereken $22,61 \mathrm{~km}^{2}$ alan ile $30,35 \mathrm{~km}^{2}$ ile karşılanabilir olduğu hesaplanmıştır.

Teşekkür: Bu çalışmaya katkılarından dolayı Sayın Recep BAYDEMIR ve Şanlıurfa Büyükşehir Belediyesi Emlak ve İstimlak Dairesi Başkanı Aydın AYDEMİR beye teşekkür ederiz.

Hakem Değerlendirmesi: Dış bağımsız.

Çıkar Çatışması: Yazarlar çıkar çatışması bildirmemiştir.

Finansal Destek: Bu çalışma, finansal olarak HÜBAP tarafından (19068 numaralı proje) desteklenmiștir.

Peer-review: Externally peer-reviewed.

Conflict of Interest: The authors have no conflict of interest to declare.

Grant Support: This study was supported by Harran University Scientific Research Council (HUBAP) with project number 19068.

\section{KAYNAKÇA/REFERENCES}

Baydemir, R. (2018). Kavramsal ve metodolojik olarak göç olgusunun mekânsal, sosyolojik ve hukuksal açıdan incelenmesi. Harran Üniversitesi Sosyal Bilimler Enstitüsü Coğrafya Anabilim Dalı (Doktora Semineri), Şanlıurfa.

Benek, S. ve Şahap, A. (2016). Uzaktan algılama ve coğrafi bilgi sistemleri kullanarak şehirsel gelişimin arazi kullanımına etkisinin incelenmesi: Şanlıurfa şehri örneği. Turkish Studies, Issn: 13082140, 79-102, Ankara.

Benek, S. ve Şahap, A. (2017). Şanlıurfa şehrinde coğrafi bilgi sistemleri (cbs) ve uzaktan algılama (ua) kullanılarak yeşil alanların yeterliliğinin belirlenmesi. Marmara Coğrafya Dergisi, 36, 304-314.

Childers, D. L. Pickett, Steward T. A. Grove, J. M. Odgen, L. \& Whitmer, A. (2014). Advancing urban sustainability theory and action: challenges and opportunities. Landscape and Urban Planning, 125, 320-328. 
Çabuk, S. N. (2015). Cbs'nin yerel yönetimlerde kullanımı ve kent bilgi sistemleri. Harita Teknolojileri Elektronik Dergisi, 7(3).

Çömert, R. Bilget, Ö. Olgay, F. Aksoy, T. Şenöz, E. ve Çabuk, A. (2016). Geotasarımın tarihsel gelişimi ve coğrafi bilgi sistemleri ile ilişkisihistorical evolution of geotasarım and relationship with gis. Doğu Coğrafya Dergisi, 21(35), 17-38.

Çullu, M. A. Ernst, F. B. Benek, S. Siverekli, E. Erdoğan, S. Aydemir, A., Yenigün, İ. Memduhoğlu, A. Karabulut, A. İ. Yıldırım, Ö. A. Karagöz, G. (2019). Harran University / Turkey.alternative futures for Şanlıurfa. First Igc Conference, On 23-25 February 2019. Redlands, Ca.

Dangermond, J. (2009). GIS: Designing our future. ArcNews, 31(2), 1, Esri, California.

Değerliyurt, M. ve Çabuk, S. N. (2015). Mcharg'ın doğayla tasarım kuramı ve geotasarım. Thejournal Of Social Science Studies, 39, 293-306.

Erinç, S. (1959). Bölge Planı Nasıl Yapılır, İstanbul Üniversitesi Coğrafya Enstitüsü Dergisi, 10, 36-51.

Erinç, S. (1984). Ortam ekolojisi ve degradasyonal ekosistem değişikliği, İstanbul Üniversitesi Rektörlüğü Deniz Bilimleri ve Coğrafya Enstitüsü, İstanbul.

Ernst, F, Çullu, M, Benek, S, Siverekli, E, Erdoğan, S, Aydemir, A, Yenigün, İ, Memduhoglu, A, Karabulut, A, Yıldırım, Ö, Karagöz, G. (2020). Design Of Development Scenarios For Şanllurfa Region Based On Geodesign, GSI Journals Serie C: Advancements in Information Sciences and Technologies, 3(2), 92-117.

Ernst, Fred. (2016). Geodesign - cbs'in geleceği. Uzaktan AlgılamaCbs Sempozyumu (Uzal-Cbs 2016), 5-7 Ekim 2016, Adana.

Ervin, S. M. (2015). Proposed map of a geodesign research agenda: eleven key questions in an eight-pole space. In Proceedings of Digital Landscape Architecture Conference, Dessau, Germany, June 4-6, 71-80.
Foster, K. (2016). Geodesign parsed: placing it within the rubric of recognized designtheories, Landscape and Urban Planning, 156, 92-100.

Hayeka, U. W. Wirth, V. Neuenschwander, N. \& Regamey, G. (2016). Organizing and facilitating Geodesign processes: Integrating tools into collaborative design processes for urban transformation. Landscape and Urban Planning, 156, 59-70.

Lee, M. (2016). Geodesign scenarios. Landscape and Urban Planning, $156,9-11$.

Lee, M. \& Gamez J. L. S. (2017). (Geo)design Coastal Cities: design with data (and nature too). The Plan Journal, 2 (2): 337-366.

Memlük, M. Z. (2009). Kentsel Mekânda Doğayla Tasarım: AnkaraBademlilere Örneği. (Yayınlanmamış Doktora Tezi). Ankara Üniversitesi Fen Bilimleri Enstitüsü Peyzaj Mimarlığı Anabilim Dali, Ankara.

Pickett, S. Boone, C. Mcgrath, B. Cadenasso, M. L. Childers, D. \& Ogden, L. (2013). Ecological science and transformation to the sustainable city. Cities, 32, S10-S20.

Steinitz, C. (2012). A framework for geodesign: changing geography by design. Redlands, CA: Esri Press.

Şenöz, E. (2013). Kaynak envanteri ve analizinde cbs desteği: geotasarım kuramının deneyimlenmesi, (Yayınlanmamış Yüksel Lisans Tezi). Anadolu Üniversitesi Fen Bilimleri Enstitüsü, Eskişehir.

Tümertekin E. ve Özgüç, N. (2006). Beşerî coğrafya insan, kültür, mekân. Ankara: Çantay Yayınları.

https:/www.projedefirsat.com/haber/sanliurfada-kentsel-donusumbasliyor Erişim Tarihi: 04.02.2020 
